\title{
Does internal board monitoring affect debt maturity?
}

\author{
Onur Kemal Tosun ${ }^{1} \cdot$ Lemma W. Senbet $^{2,3}$
}

Published online: 19 January 2019

(C) The Author(s) 2019

\begin{abstract}
Using the Sarbanes-Oxley Act (SOX) as an exogenous shock to board structure, we identify internal monitoring via board independence and estimate its impact on corporate debt maturity. We introduce a triple difference-in-difference approach. Additionally, we use a simultaneous equations model and address that decisions about leverage and debt maturity are simultaneous. We also incorporate new debt issuance in the model to ensure the causality in the relation is from internal monitoring towards the maturity of new debt. The findings provide support for agency theory. As board independence increases, internal monitoring becomes stronger, and good governance substitutes for external control over managers through short-term debt. Subsequently, firms have more long-maturity debt. The results are robust to controlling for other internal monitoring mechanisms, CEO characteristics, financial constraints, cash, bond ratings, yield, and debt seniority. The impact of increased board independence on debt maturity is more significant for conglomerates and cases where there is a greater need for internal control over managers, such as CEO duality, high GIM index, straight debt, less strict covenants, high intangibility, high free cash flow, no majority blockholders, high discretionary accruals, or high real earnings management. In further analyses, we rule out the concern that our results are due to better reporting of internal controls through SOX Section 404 or an increase in auditors' liability after SOX, rather than increased board independence.
\end{abstract}

Keywords Corporate governance $\cdot$ Board duality $\cdot$ Debt maturity $\cdot$ Agency issue $\cdot$ Board independence

JEL Classification C33 $\cdot \mathrm{C} 36 \cdot \mathrm{G} 32 \cdot \mathrm{G} 38$

Electronic supplementary material The online version of this article (https://doi.org/10.1007/s 1115 6-018-00787-z) contains supplementary material, which is available to authorized users.

Onur Kemal Tosun

Onur.Tosun@wbs.ac.uk

Lemma W. Senbet

1senbet@rhsmith.umd.edu

1 Warwick Business School, University of Warwick, Coventry, UK

2 Robert H. Smith School of Business, University of Maryland, College Park, MD, USA

3 African Economic Research Consortium, Nairobi, Kenya 


\section{Introduction and related literature}

Decisiveness about the maturity structure of debt is crucial for all firms because they implement their investment policies, plan the duration of their projects, and manage their operations accordingly. Many studies have examined the determinants of debt maturity. Some explore certain firm characteristics, while others research the features of loans and the bond market conditions. In this article, we expand on the existing literature and investigate the effects of corporate governance changes on the debt maturity structure of a firm. Specifically, we focus on internal board monitoring via changes in board independence and how these changes influence the maturity of a firm's debt. To identify the cause of this relation, we use an exogenous shock that influences only the governance structure of firms. Subsequently, we examine the changes in internal control over managers and the potential impact on debt maturity.

Our main research question is whether, with strong governance through increased board independence, a larger proportion of a firms' debt has relatively longer maturity. According to the agency theory, managers can extract benefits from debt by investing lenders' money in riskier projects or through moral hazard (e.g. wasteful investment and managerial perks) when the monitoring mechanism is weak. In such a case, Petersen and Rajan (1995) and Stulz $(1990,2000)$ state that banks and lenders in the bond market prefer short-term debt because short-term maturity requires the continuous renewal of the contract between the firm and the lender. This allows creditors to control managers externally with minimum effort and may also prevent managers from engaging in opportunistic behavior, such as shirking, wealth shifting, risk shifting and free cash flow. Alternatively, managers can be monitored internally by good corporate governance. Fama (1980) suggests that, as the ratio of external to internal directors increases, the board becomes more independent and objective.

We seek to establish a link between debt maturity and strong internal monitoring through increased board independence. We hypothesize that creditors may prefer more long-term debt when firms have more independent and stronger boards because external control is already substituted by internal monitoring. ${ }^{1}$ Figures 2,3 and 4 confirm the link between more independent boards and long-term debt. As the board becomes stronger, there is less need for external monitoring through short-term debt. Hence, investors may agree on debt with longer maturity.

Turning to the literature, numerous authors (Barclay et al. 1995; Guedes and Opler 1996; Ozkan 2000; Scherr and Hulburt 2001; Elyasiani et al. 2002; Jun and Jen 2005; Faulkender and Petersen 2006; Erhemjamts et al. 2010; Dang 2011; Brick and Liao 2017) suggest that leverage, growth options, asset maturity, profitability, cash, tangibility and industry conditions are the primary determinants for debt maturity decisions. Chen et al. (1999) and Gupta and Lee (2006) suggest that, in addition to growth options,

\footnotetext{
1 As an alternative channel to the creditor-driven force, there may be a firm-centric explanation: as internal board monitoring becomes stronger through increased board independence, the CEO is conditioned to take a longer-term view in her strategy, and so she decides on long-term investments. If so, due to 'duration matching' of investment to financing, the CEO decides on more long-term debt. A mechanism deriving our results might be that corporate governance and debt maturity are complementary. One of the roles of good governance is to implement the optimal maturity structure. Under this framework, evidence that firms increase their debt maturity when good governance is imposed by SOX and then by SEC regulations might also mean that, for these firms, long-term debt is optimal and that, after good governance is in place, they finally change to optimal debt maturity.
} 
firm size is also an important factor for lenders. Billett et al. (2007) maintain that covenants can mitigate the agency cost of debt for high-growth firms. They find that covenant protection is increasing with regard to growth opportunities and debt maturity. Rokkanen (2010) examines firm reputation as a determinant of the maturity of newly issued debt, and finds that firms with a high or low reputation issue short-term debt while firms with a mediocre reputation have long-term debt. Jun and Jen (2003) use a trade-off model to explain the choice of debt maturity. They suggest that only firms with greater financial flexibility and financial strength can have more short-term debt. Tosun (2016) and Brockman et al. (2010) focus on the incentive features of managerial compensation to explain debt and debt maturity. They show that debt decreases as the CEO is paid with more stock options, and that there is a negative (positive) relation between CEO portfolio deltas (vegas) and short-maturity debt. Saretto and Tookes (2013) investigate credit default swap (CDS) contracts and find that firms with traded CDS contracts on their debt are able to maintain higher leverage and longer debt maturities.

Barnea et al. (1980), Mitchell (1991), and Goyal and Wang (2013) consider the case of information asymmetry in firms and its implications for the maturity structure of debt. They show that firms with favorable information, and hence a high degree of information asymmetry, have debt with shorter maturity. Barnea et al. (1980) explain that short-term debt mitigates the debt agency issue associated with the wealth transfer from bondholders to stockholders. Anderson et al. (2004) examine S\&P 500 Industrial firms for the period from 1993 to 1998 and show that greater board independence is associated with lower corporate-debt yield spreads. Arslan and Karan (2006) consider companies with large shareholders and concentrated ownership structure, and find that those firms are characterized by longer debt maturity. Conversely, Ben-Nasr et al. (2015) use publicly traded French firms between 1998 and 2013 and show that the presence of multiple large shareholders is linked to shorter debt maturity. Using a sample of 763 leveraged buyouts (LBOs) completed between 1984 and 1989, Cotter and Peck (2001) find that, when buyout specialists have the majority of the firm's ownership, the LBO transaction is likely to be financed with less short-term and/or senior debt. Jiraporn and Kitsabunnarat (2007) use a two-stage least squares regression analysis and show that managers of firms with weak shareholder rights avoid debt with shorter maturity to minimize external monitoring.

In this article, we build on the growing literature and investigate corporate governance in relation to debt maturity. We investigate this potential relationship by analyzing an exogenous shock to the governance structure, particularly the Sarbanes-Oxley Act (SOX) of 2002 and the resulting corporate governance rules enforced by the Securities and Exchange Commission (SEC). SOX is a United States federal law that sets enhanced standards for all US public company boards and management. The Act comprises 11 sections, ranging from additional corporate board responsibilities to criminal penalties, and requires the SEC to implement rulings on requirements to comply with the law. Following that amendment, corporate governance rules were enacted for the NYSE and the NASDAQ under Sections 303A and 5605A, respectively. One of the regulations for the listed companies is the requirement for majority independence of the board of directors:

... 'Independent Director' means a person other than an Executive Officer or employee of the Company or any other individual having a relationship which, in the opinion of the Company's board of directors, would interfere with the exercise of independent judgment in carrying out the responsibilities of a director. ... A majority of the board of directors must be comprised of Independent Directors... 
Consequently, listed firms without a majority independent board have to increase the number of independent directors. SOX and the SEC listing requirements should have no direct influence on corporate debt maturity. Hence, we use this regulatory change as a valid exogenous shock in the experiment. We conduct a triple difference-in-difference (DID) analysis. We compare the debt maturity of non-compliant (treatment) companies before and after the legislation and observe how changes in board independence in the post-period influence the maturity structure of the debt of those treatment firms. We also conduct a similar exercise for the control firms that were compliant with the board independence regulation prior to 2002. Including these control firms in the analysis helps us to take any contemporaneous impact on firms out of the main effect we demonstrate. Subsequently, we are able to show the influence of changes in board independence on the debt maturity structure of non-compliant firms in comparison to the control firms before and after the shock.

We find that firms have debt with longer maturity as board independence increases and internal board monitoring becomes stronger. ${ }^{2}$ This supports the idea of substitution of external control by internal monitoring. The findings are consistent with the agency theory framework. The impact of increased board independence on debt maturity is more significant for conglomerates and cases where there is a greater need for internal control over managers, such as CEO duality, high GIM index, ${ }^{3}$ straight debt, less strict covenants, high intangibility, high free cash flow, no majority blockholders, high discretionary accruals, or high real earnings management.

Wintoki (2007) argues that a blanket "one size fits all" governance regulation may not be optimal for some firms. Tosun (2018) discusses how externally dictated governance rules can be harmful for some firms and decrease firm performance. Adams and Ferreira (2007) suggest that friendlier and less independent boards may be optimal for firms that need advice (rather than monitoring) from their board of directors. Engel et al. (2007), Zhang (2007), and Iliev (2010) argue that the additional costs SOX imposes on some firms exceed the benefits of the legislation. In this paper, we do not investigate the cost of SOX to firms or the optimality of SOX and the SEC regulations. Instead, we examine the impact of stronger governance on firms' financing choices, particularly debt maturity. The imposed rules about board independence may not be optimal for all companies and may have an insignificant effect on debt maturity for some firms. Despite the possible insignificance and noise coming from those companies in our sample, we still obtain significant outcomes considering all firms for which SOX and the SEC requirements may (or may not) be optimal.

In this study, we use SOX and the SEC listing requirement regarding the rule on board independence, and we have a natural experiment setup similar to that of Guo et al. (2015) and Guo and Masulis (2015). While their research focuses on internal and external governance mechanisms and forced CEO turnover sensitivity to firm performance, respectively, we investigate the relation between corporate governance and debt maturity decisions. Harford et al. (2008) use a two-stage least squares regression analysis and suggest that stronger boards are in a better position to force reluctant managers to undergo the scrutiny of short-term-creditor monitoring. Our study is closely related to theirs. However, unlike them, we show that external control through short-term debt is a substitute for internal control through board monitoring. Our research differs from theirs in that we address the

\footnotetext{
2 From the "supply of debt" point of view, firms affected by the legislation may have obtained greater access to longer-term debt due to reduced uncertainty about their financial condition.

3 The broad-based governance index constructed by Gompers et al. (2003).
} 
endogeneity issue in the relation between governance and debt maturity using the SOX rule leading to the SEC board independence requirement as the exogenous shock in a natural experiment setting. We also incorporate new debt issuance in the model to ensure that the causality in the relation is from internal monitoring towards the maturity of new debt. Moreover, we use an instrumental variable (IV) regression model similar to the one suggested by Duchin et al. (2010) to control for potential endogeneity in corporate governance changes.

Barclay et al. (2003) and Johnson (2003) argue that decisions about leverage and debt maturity are simultaneous. To include intertemporal dependencies within variables and control for the omitted variables bias, we use a simultaneous equations model. ${ }^{4}$ In the first stage, we predict leverage via lagged debt maturity measures, and, in the second stage, use the estimated leverage as a control.

In further analyses, we control for any potential influence on debt maturity from financial constraints, blockholders, CEO ownership, CEO tenure, bond ratings, debt covenants, convertible debt, seniority of debt, yield of debt, industry competition, and small cap firms. We also investigate whether other internal monitoring mechanisms may explain our results. Moreover, we examine different levels of cash holdings and asset maturity. Further, we regress the debt maturity measures on the interaction of the independence measure with year dummies. Supporting our main findings, we show that post-event years have statistically different results from pre-event years. We also test, through placebo analysis, whether there are other firm-related endogenous shocks or independent exogenous shocks that affect the relation between changes in board independence and debt maturity. We find that this regulatory change is the only valid shock in the analysis period. This study covers a time span of 14 years around the event. We also conduct the analysis for shorter terms-for example, 10 years. We examine other SOX rules and the SEC regulations, as well as auditors' increased exposure to liability in relation to corporate debt maturity. In particular, we try to separate the effect of increased board independence from any influence from SOX Section 404, which also focuses on internal control.

We address possible concerns about the model and alternative explanations for the findings. It might be argued that the increase in the long-term debt ratio in the postperiod is mechanical and is caused only by the reduction in the short-term debt level, not necessarily by the increase in long-term debt. Conversely, Figure 5 in the "Appendix" demonstrates that long-term debt holdings rise drastically following the amendments. It might be possible that, after the regulatory change, there is an increase in the supply of longer-term debt by external capital providers. This could derive the increase in long-term debt for the treatment firms. However, a potential increase in long-term debt supply would influence all companies, not only the treatment firms. As such, one should expect to see an overall increase in the long-term debt level across firms. However, we find that only the treatment firms have more debt with longer maturity. It might also be suggested that the substitution effect through external control is in fact due to the disciplinary role of debt rather than its maturity, because debt and maturity are simultaneous decisions. This is not a concern in our study. We acknowledge this factor by controlling for firm leverage in all analyses. We also have a simultaneous equations model where we use leverage as the dependent variable in the first step of equations. Hence, we address the simultaneity of leverage and debt maturity while examining

\footnotetext{
4 In untabulated analyses, we also include the residual leverage from the first-stage estimation in the second-stage analysis. The original results remain robust.
} 
board independence. Another issue might be the convertibility feature of firm debt. As this allows lenders to switch to stocks at any given time, creditors may prefer convertible debt with longer maturity. Subsequently, companies may have more long-term debt if they issue more convertible debt than straight debt. We show that this is not the case because both the straight and convertible debt holdings display similar distribution patterns over the years studied.

An alternative explanation for our findings might be the yield structure and cost of debt. We investigate this possibility and find that the yield for short-term loans decreases more than the yield for long-term loans in the post-event period. Further, the rates for companies' short-term bonds increase, while the rates for long-term bonds decrease. These conditions suggest that firms should have more short-term loans, as they are cheaper, and lenders should choose short-term bonds because they offer higher returns. However, we show a decrease in the short-term debt ratio in the post-event period as board independence increases. Hence, the yield of loans and the cost of debt cannot explain our results.

It might be argued that SOX affected a variety of components in a firm with the goal of preventing corporate fraud, many of which might potentially influence debtholder concerns about the firm. However, this should not be a concern in this paper. We explicitly analyze the change in board independence in non-compliant firms after SOX and the SEC regulations through the triple interaction variable. We control other factors, including the potential effects of other SOX provisions, through the Post*Treatment dummy in the model. The results are stronger and significantly different for the triple interaction term compared to the Post* Treatment dummy.

Other potential issues affecting the results might be the rapid growth of the CDS market in the late 1990s, the change in repo markets in the mid-to-early 2000s, and the illiquidity factor during times of financial crisis. These noises may coincide with SOX and the SEC rules, but they do not have a direct effect on the outcome variable. The emergence of the CDS market is more of a growing trend over time rather than an instant shock. Because of this, year fixed effects control for any influence by the trend in the CDS market over the period studied. Additionally, placebo tests capture whether the CDS market has any impact on debt maturity at any time. The change in the repo markets and market illiquidity affect all firms in the post-event period, and the Post*Treatment dummy in the model controls for these factors. In this study, we primarily examine the effect of changes in board independence in non-compliant firms during the post-event period through the $\Delta$ Board Independence *Post*Treatment variable. If repo markets and illiquidity were the main causes for the results, then we should find similar coefficient estimates for Post $*$ Treatment and $\Delta$ Board Independence $*$ Post $*$ Treatment; that is, the addition of $\Delta$ Board Independence should not create any changes in the results. However, the interaction variable presents significantly different findings.

Another possible concern might be the conflict between the managerial agency and debt agency issues. We suggest that the managerial agency problem may be resolved by improved internal control. This can lead to an alignment between managers and shareholders, acting against debtholders that might aggravate the debt agency issue. This is not the case in this paper because it supports the "board duality" hypothesis. Improved governance with more independent directors serves all stakeholders, focusing on firm value maximization, rather than equity (ex-post) value maximization. Subsequently, better governance may mitigate both agency problems. We research the board composition following the amendments. We find that $30 \%$ of independent directors (17\% of the entire board) have occupations associated with the stakeholder concept while only $10 \%$ of independent board members (13\% of all members) can be linked to the shareholder concept. 
We contribute to the literature by showing board independence as one of the determinants of debt maturity. Using various advanced methods, we provide more insight into this relation by examining cases with a greater need for internal control, different debt features, organizational structure, and financial crises. Our findings will be useful for policymakers formulating regulations on corporate governance relating to implications for capital structure and financing decisions. In particular, board independence can be used as a vehicle of credibility for long-term financing for emerging economies where alternative mechanisms for resolving the debt agency issue are more costly.

The external validity of our findings can be tested in further extended research. Additional analyses may be conducted through public or private debt. Using similar regulations in various countries, a cross-country examination may bring more insight to the relation between corporate governance and the maturity structure of debt.

The remainder of the paper is organized as follows. In Sect. 2, we describe the data selection and variable construction. Section 3 discusses the initial findings. Section 4 explains the empirical method used to examine changes in board independence and their relation to debt maturity. Section 5 provides the main results and further analyses. In Sect. 6, we conclude.

\section{Data selection and variable construction}

We collect our data from the Compustat, CRSP, and ISS (formerly RiskMetrics) databases 1996-2009. In order to balance the period leading to the sub-prime crisis, we determine a 7-year period either side of the event. We use Thomson Reuters Dealscan when there are any missing data on debt maturity in Compustat. We restrict the variables to have observations both in the pre-event and the post-event period. We require total assets to have a greater value than capital expenditures, and both to have positive values. We drop data where total liabilities are greater than total assets, and where the sum of long-term and short-term debt is greater than total assets. Financial firms and utilities are excluded. We winsorize the variables with extreme values at $1 \%$ and $99 \%$. The sample comprises 8715 observations with 1152 firms.

We define $\Delta$ Board Independence as the change in the percentage of independent members of the board of directors between the current and the preceding year. This measure reflects the change in the level of internal control over managers and the strength of corporate governance. Following Barclay et al. (1995), Ozkan (2000) and Johnson (2003), we evaluate the maturity structure of debt using three different variables. Short-Term Ratio (ST Ratio) is current liabilities over the sum of current liabilities and long-term debt. This measure concentrates on the debt maturing in up to 1 year. Long-Term Ratio (LT Ratio) is the sum of debt maturing in more than 2 years over the total debt. This measure focuses on the long-term horizon of the firm's debt. Weighted Average Maturity (WAM) is calculated by multiplying the fraction of each type of debt with its maturity in years. This variable considers different maturities separately and amplifies the weight of debt in the measure according to its maturity length. ${ }^{5}$

\footnotetext{
${ }^{5}$ We also define $L T$ Ratio as the sum of debt maturing in more than 5 years over the total debt, and obtain robust results.
} 
Following the debt maturity literature, we use several control variables. $M / B$ represents the market-to-book ratio through the common shares outstanding multiplied by the closing price of one share over the common equity. Growth is capital expenditures over total assets. Yield is the federal fund interest rate. Size is the natural logarithm of total assets. Tangibility is property, plant and equipment total over total assets. Profitability is earnings before interest and taxes over total assets. Cash is cash and short-term investments over total assets. Volatility is the standard deviation of daily stock returns. Asset Maturity is the ratio of fixed assets over annual depreciation expense. Leverage is the sum of current liabilities and long-term debt over total assets. HHI is the Herfindahl measure for the industry concentration computed via the Text-based Network Industry Classifications method suggested by Hoberg and Phillips (2010). ${ }^{6}$

We construct treatment and control groups in the sample using propensity score matching for the random assignment of firms. We propensity-match non-compliant (treatment) firms with at least the two nearest compliant neighbor firms in the sample using characteristics known to affect the maturity structure of debt, which are the control variables in our model. After the matching, those firms that complied with the requirement of majority board independence prior to 2002 will be the control firms. We check whether these treatment and control groups are similar in those firm characteristics and differ only in board independence. Table 1 implies that both groups have similar mean values for firm characteristics, yield, and industry concentration but differ in board independence. Further comparison of these variables in terms of mean differences can be found in Table 1. At the end, we obtain 346 treatment and 806 control firms that we use in all analyses.

Table 1 provides the summary statistics for all variables. In the total sample, $26 \%$ of the debt has maturity up to 1 year (28\% for treatment firms and $25 \%$ for the control group). The right-skewed feature of Short-Term Ratio suggests that some firms have a large amount of debt with short-term maturity. Long-Term Ratio indicates that, on average, $65 \%$ of the firm's debt matures in at least two years. Long-Term Ratio is $61 \%$ for non-compliant firms and $66 \%$ for control firms. The average maturity of debt is about 3 years and 8 months for all firms combined. It is slightly shorter ( 3 years and 7 months) for treatment firms and slightly longer ( 3 years and 9 months) for compliant firms. Average board independence is $68 \%, 59 \%$ and $75 \%$ respectively for overall sample, treatment, and control firms. The statistics for firm characteristics are similar to those documented in previous studies. The average federal fund rate in the sample period is about $3.8 \%$. The mean $H H I$ value of 0.136 indicates that the firms in our sample operate in competitive industries. When comparing treatment firms to control firms in terms of the descriptive statistics, we find that both groups have similar mean values for firm characteristics, interest rate, and industry concentration.

We examine the distribution for the board independence and debt maturity measures separately for both types of firms that did and did not comply with board independence requirement prior to 2002. In this way, we can observe any trends among compliant firms and compare those to non-compliant firms. Figure 1 shows the annual mean values of Board Independence and Short-Term Ratio. Before SOX and the SEC regulation, Board

\footnotetext{
6 We also use US 10-year Treasury and US three-month Treasury yields to control for the long-term and the short-term interest rates. We use the yield spread, too. Alternatively, we define Size as the natural logarithm of net sales. We also compute Asset Maturity as: (gross property, plant, and equipment/total assets $) \times($ gross property, plant, and equipment/depreciation expense $)+($ current assets/total assets $) \times($ current assets/cost of goods sold). We obtain similar results.
} 
Table 1 Descriptive statistics of variables

\begin{tabular}{|c|c|c|c|c|c|c|c|c|c|c|}
\hline \multirow[t]{2}{*}{ Variables } & \multicolumn{3}{|c|}{ Total sample } & \multicolumn{3}{|c|}{ Treatment firms } & \multicolumn{3}{|c|}{ Control firms } & \multirow{2}{*}{$\begin{array}{l}\text { Mean } \\
\text { Difference }\end{array}$} \\
\hline & Mean & Stdev & P50 & Mean & Stdev & P50 & Mean & Stdev & P50 & \\
\hline Short term ratio & 0.256 & 0.273 & 0.146 & 0.287 & 0.311 & 0.153 & 0.248 & 0.269 & 0.145 & \\
\hline Long term ratio & 0.649 & 0.296 & 0.730 & 0.612 & 0.330 & 0.725 & 0.664 & 0.291 & 0.730 & \\
\hline Weighted average maturity & 3.690 & 1.334 & 3.801 & 3.631 & 1.350 & 3.935 & 3.729 & 1.332 & 3.785 & \\
\hline Board independence & 0.679 & 0.169 & 0.714 & 0.593 & 0.183 & 0.571 & 0.751 & 0.113 & 0.750 & \\
\hline Leverage & 0.204 & 0.208 & 0.153 & 0.200 & 0.184 & 0.178 & 0.204 & 0.211 & 0.149 & -0.004 \\
\hline Profitability & 0.058 & 0.020 & 0.059 & 0.067 & 0.018 & 0.080 & 0.057 & 0.020 & 0.054 & 0.010 \\
\hline Asset maturity & 0.152 & 0.165 & 0.109 & 0.153 & 0.122 & 0.124 & 0.151 & 0.169 & 0.106 & 0.002 \\
\hline $\mathrm{M} / \mathrm{B}$ & 2.111 & 0.598 & 2.000 & 2.201 & 0.572 & 2.345 & 2.106 & 0.600 & 1.948 & 0.095 \\
\hline Size & 5.399 & 0.579 & 5.260 & 5.539 & 0.346 & 5.891 & 5.318 & 0.576 & 5.003 & 0.221 \\
\hline Growth & 0.058 & 0.068 & 0.035 & 0.058 & 0.057 & 0.040 & 0.058 & 0.069 & 0.035 & 0.000 \\
\hline Tangibility & 0.189 & 0.078 & 0.177 & 0.200 & 0.075 & 0.210 & 0.188 & 0.078 & 0.172 & 0.011 \\
\hline Cash & 0.129 & 0.071 & 0.112 & 0.122 & 0.069 & 0.095 & 0.130 & 0.071 & 0.114 & -0.008 \\
\hline Volatility & 0.137 & 0.189 & 0.136 & 0.130 & 0.167 & 0.117 & 0.137 & 0.189 & 0.139 & -0.007 \\
\hline Yield & 3.774 & 1.893 & 4.970 & 3.728 & 1.901 & 4.970 & 3.778 & 1.892 & 4.970 & -0.051 \\
\hline HHI & 0.136 & 0.050 & 0.123 & 0.128 & 0.049 & 0.102 & 0.137 & 0.050 & 0.127 & -0.010 \\
\hline
\end{tabular}

This table provides descriptive statistics of variables regarding the entire sample and the subsamples of treatment and control firms. Mean differences between treatment and control groups are given. There are 1152 firms with 8715 firm-year observations. Short-Term Ratio is current liabilities over the sum of current liabilities and long-term debt. Long-Term Ratio is the sum of the debt maturing in more than 2 years over the total debt. Weighted Average Maturity is calculated via multiplying the fraction of each type of debt with its maturity in years. Board Independence is the percentage of the independent members of the board of directors. $M / B$ represents market-to-book ratio and it is common shares outstanding multiplied by the closing price of one share over the common equity. Growth is capital expenditures over total assets. Tangibility is property, plant, and equipment total over total assets. Profitability is the earnings before interest and taxes over total assets. Cash is the ratio of the cash and short-term investments over total assets. Volatility is the standard deviation of daily stock returns. Yield is the Federal Funds Interest Rate in percentage. Size is the natural logarithm of total assets. Asset Maturity is the ratio of the fixed assets over the annual depreciation expense. Leverage is the sum of current liabilities and long-term debt over total assets. HHI is the Herfindahl measure for the industry concentration that is computed via the Text-based Network Industry Classification method by Hoberg and Phillips (2010)

Independence fluctuates between $44 \%$ and $48 \%$ for non-compliant firms and between $72 \%$ and $76 \%$ for compliant firms. Short-Term Ratio is about $31 \%$ and $25 \%$ for treatment and control firms, respectively. After the regulatory change, Board Independence jumps by $16 \%$ to $64 \%$ for non-compliant firms and rises to $76 \%$ by 2009 . Conversely, Short-Term Ratio drops rapidly from $30 \%$ to $24 \%$ in 2003 and stays around that level until 2009. This figure suggests a negative relation between board independence and short-term debt for non-compliant companies following the legislation. After the event, Board Independence increases slightly to $78 \%$ for compliant firms. The Short-Term Ratio for compliant firms does not decrease significantly, but rather fluctuates between $26 \%$ and $24 \%$. This figure implies that short-term debt in those firms is not markedly affected after the regulatory change.

Figure 2 displays the annual mean values of Board Independence and Long-Term Ratio measures. Before the event, Long-Term Ratio fluctuates between 56\% and $62 \%$ for non-compliant firms while it is around $65 \%$ for compliant firms. After the enactment, 


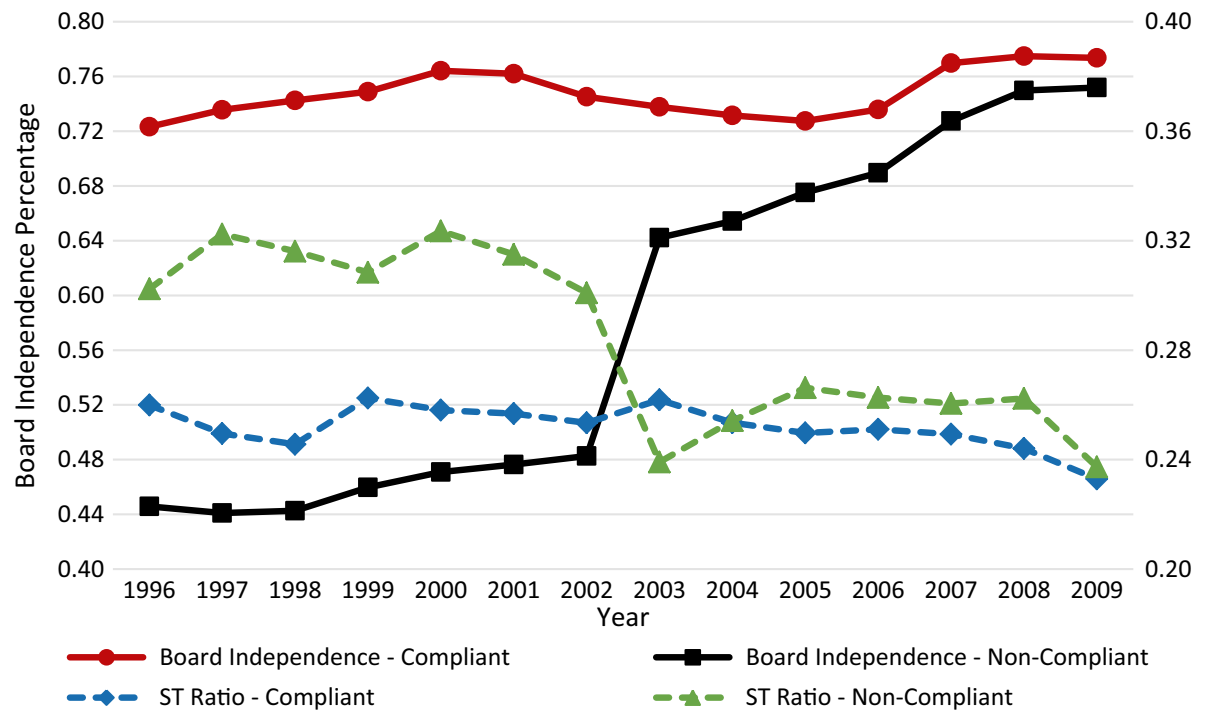

Fig. 1 Distribution of Board Independence and Short-Term Debt Ratio. This figure displays the distribution of the mean values for Board Independence and Short-Term Ratio between 1996 and 2009. The measures are given separately for both Compliant and Non-Compliant firms. Variable definitions are available in Table 10, "Appendix"

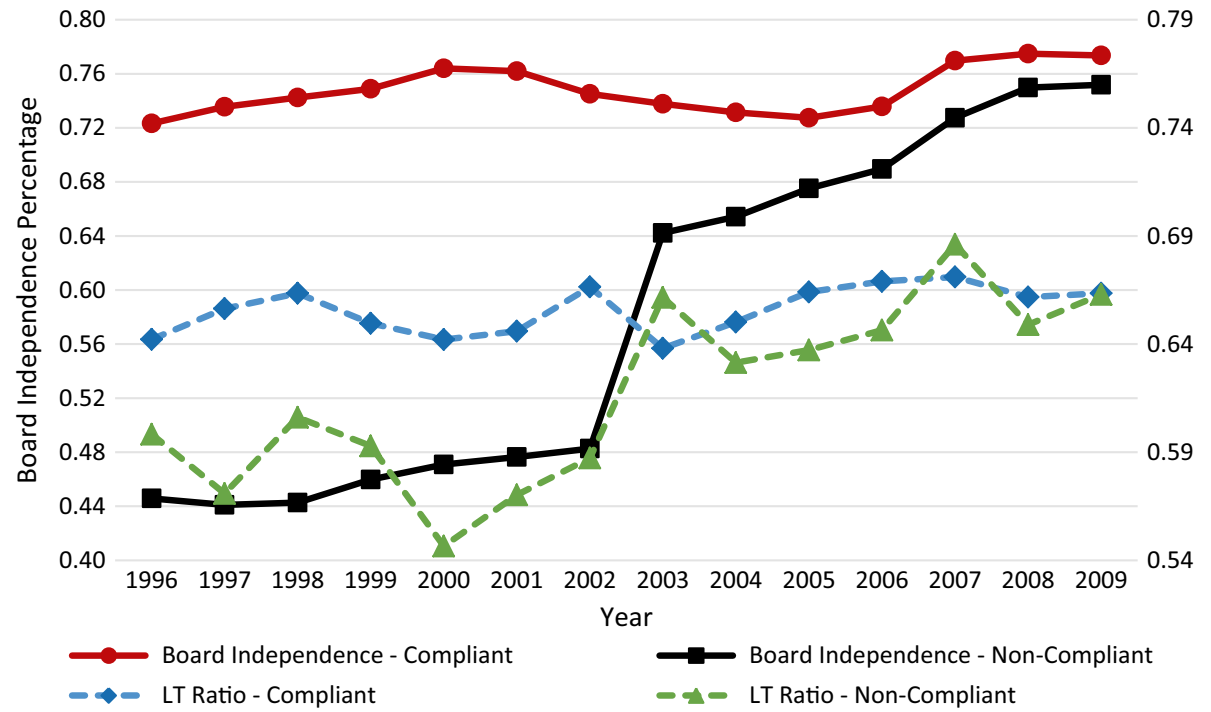

Fig. 2 Distribution of Board Independence and Long-Term Debt Ratio. This figure displays the distribution of the mean values for Board Independence and Long-Term Ratio between 1996 and 2009. The measures are given separately for both Compliant and Non-Compliant firms. Variable definitions are available in Table 10, "Appendix"

Long-Term Ratio for non-compliant firms increases drastically from 59\% to $67 \%$ and their maturity structure becomes similar to that of the compliant firms. Debt with longer-term 


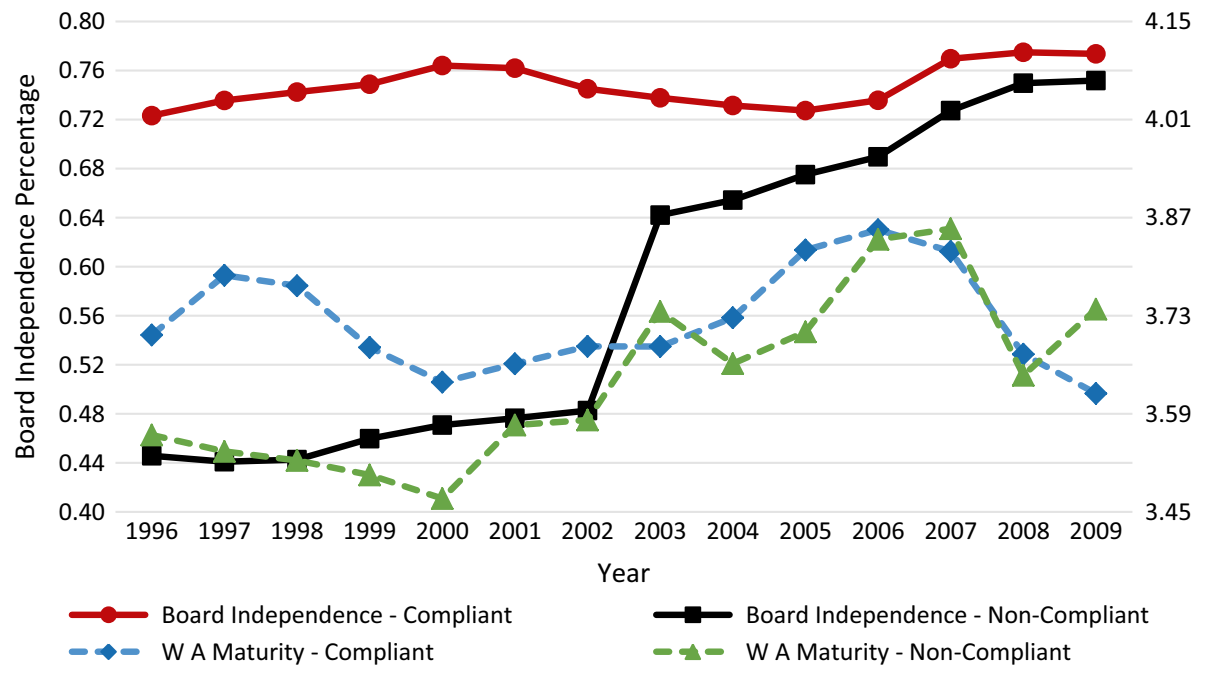

Fig. 3 Distribution of Board Independence and Weighted Average Maturity. This figure displays the distribution of the mean values for Board Independence and Weighted Average Maturity between 1996 and 2009. The measures are given separately for both Compliant and Non-Compliant firms. Variable definitions are available in Table 10, "Appendix"

maturity for those compliant firms does not change much after the event. However, this figure suggests a positive relation between board independence and long-term debt for noncompliant firms.

Figure 3 shows the annual mean values of Board Independence and Weighted Average Maturity measures. Weighted Average Maturity for non-compliant firms is between 3.50 and 3.59 years before SOX, while it fluctuates between 3.66 and 3.79 for control firms. Afterwards, treatment firms catch up with the control firms and they have a similar maturity structure. Weighted Average Maturity for those firms rises to 3.87 by 2007 and drops soon after. The maturity of debt in non-compliant firms is not significantly affected following SOX and the SEC regulation. This figure suggests that there is a positive relation between board independence and debt with longer maturity for compliant companies.

\section{Initial analyses}

Table 2 provides results for the mean comparison $T$ test. We compare the pre-period measures to the post-period measures for board independence and debt maturity to observe any significant differences in means. We conduct tests for both treatment (non-compliant) and control (compliant) firms. The results for treatment firms are statistically significant at the $1 \%$ level. In particular, Board Independence increases significantly (by 23\%) after the event. It shows the influence of the SOX regulation leading to the SEC listing requirement as the shock on corporate governance. Short-Term Ratio declines about $5 \%$ on average after the shock, while Long-Term Ratio increases by 6\%. Likewise, Weighted Average Maturity increases by 2 months, from 3.54 to 3.70 years. The findings indicate that treatment firms 
Table 2 Mean comparison test for board independence and debt maturity measures

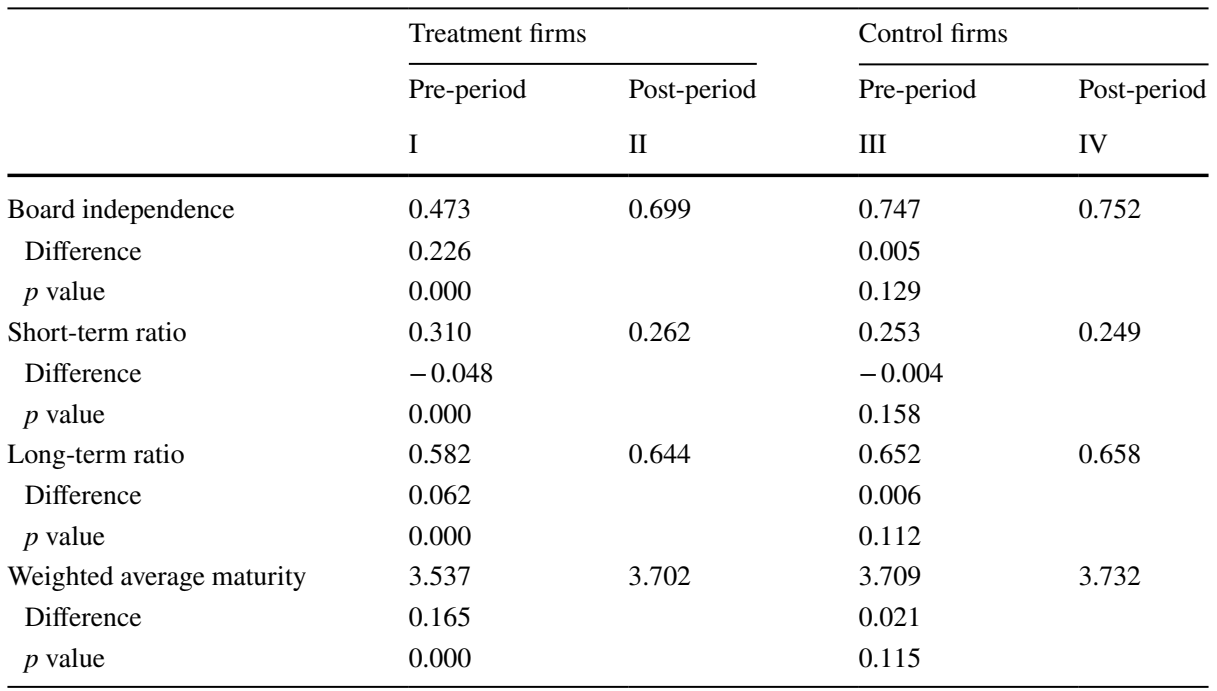

This table presents results of the mean comparison T-test for Board Independence, Short-Term Ratio, Long-Term Ratio, and Weighted Average Maturity. The tests are conducted separately for treatment and control firms. The mean values are given for the pre-period (1996-2002) and the post-period (2003-2009), respectively. The mean difference and associated $p$ values are provided. Variable definitions are available in Table 10, "Appendix"

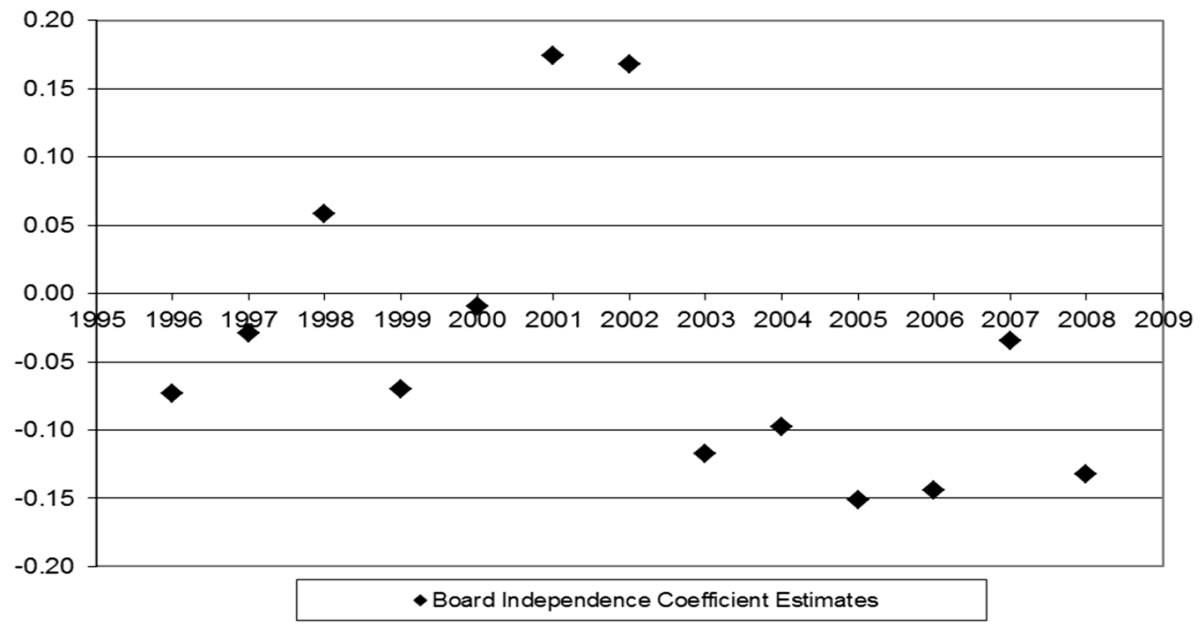

Fig. 4 Board Independence Coefficient Estimates for Short-Term Ratio. This figure displays coefficient estimates for Board Independence in the cross-sectional OLS Regression Analysis for each year. The analysis focuses on treatment (Non-Compliant) firms. The dependent variable is Short-Term Ratio. Board Independence is the percentage of the independent members of the board. Short-Term Ratio is current liabilities over the total debt. Control variables are included. Standard errors are clustered at the firm level 
have a larger proportion of debt with relatively longer maturity as the board becomes more independent afterwards. Similar results hold for the median values of these variables. In Columns III and IV of Table 2, the findings are statistically insignificant for control firms. On average, board independence and debt maturity measures have around the same values before and after the event. This implies that SOX and the SEC listing requirement do not have any significant influence on board independence for control firms, and the maturity structure of debt does not change.

Figure 4 presents coefficient estimates for Board Independence in the cross-sectional OLS regression analysis for each year. We focus on treatment firms and regress Short-Term Ratio on Board Independence along with the control variables and record the estimates. In the years before the event, the estimates for Board Independence are scattered between 0.05 and -0.05 , while the coefficients are clustered between -0.10 and -0.15 after the shock. The results suggest that the changes in Board Independence are not due to any trend across the years. Conversely, the estimates are clustered in different regions before and after the amendment. The change between these two clusters immediately following the shock shows the impact of the SOX enactment leading to the SEC listing requirement on board independence.

\section{Empirical methodology}

The period for the experiment is 1996-2009. We have a balanced sample around the legislation. We compare the seven-year periods before and after the event. Both periods include a 3-year time interval representing a financial crisis, namely the 2000-2002 stock market crash due to the dot-com bubble and the 2007-2009 subprime mortgage crisis.

The experiment is conducted via a triple difference-in-difference analysis. We use dummy variables for the post-period and treatment firms along with the interactions of these variables with the change in board independence measure. Subsequently, we can examine all possible effects from governance measure variations on the maturity structure of debt. In this study, we try to show that debt maturity changes arise through the corporate governance channel. We aim to identify how much the maturity structure of debt is affected by the increases (decreases) in board independence for treatment firms after the amendment. We investigate whether, in the post-event period, board independence changes have a greater impact on leverage for treatment firms than an identical governance change for a control firm. This argument is denoted by the interaction of $\Delta$ Board Independence with the Post and Treatment dummies. The treated firms are the companies that did not comply with the board independence requirement prior to 2002. The post-period data cover all observations after 2002. $\Delta$ Board Independence *Treatment, $\Delta$ Board Independence * Post, Post $*$ Treatment, and $\Delta$ Board Independence *Post $*$ Treatment are the interaction variables of Post, Treatment, and $\Delta$ Board Independence. Year and firm fixed effects, ${ }^{7}$ along with the controls (M/B, Growth, Yield, Size, Tangibility, Profitability, Cash, Volatility, Asset Maturity, Leverage, and $H H I$ ) are added to the model. The model does not include indicators for

\footnotetext{
7 In further analyses, we replace firm fixed effects with industry fixed effects and obtain similar robust results.
} 
the treatment firms or the post-period individually since they are subsumed in the firm and year fixed effects. Standard errors are clustered at the firm level. The model is specified as follows:

$$
\begin{aligned}
Y_{i, t}= & \alpha+\beta * X_{i, t}+\theta * \text { Post }_{i, t} * \text { Treatment }_{i, t}+\gamma * X_{i, t} * \text { Post }_{i, t} \\
& +\lambda * X_{i, t} * \text { Treatment }_{i, t}+\phi * X_{i, t} * \text { Post }_{i, t} * \text { Treatment }_{i, t}+\sum_{k=1}^{11} \delta_{k} * \text { Controls }_{i, t, k}+\mu_{i, t}
\end{aligned}
$$

where the debt maturity measure is $\mathrm{Y}$; the change in board independence measure is $\mathrm{X}$; the firm observation is $\mathrm{i}=1, \ldots, \mathrm{N}$; the entire period is $\mathrm{t}=1996, \ldots, 2009$; the number of control variables is $\mathrm{k}=1, \ldots, 11$; and the constant term and the coefficients of the change in board independence, treatment firms in the post-period, board independence changes in the post-period, treatment firms' board independence changes, treatment firms' board independence changes in the post-period, controls, and error term are $\alpha, \beta, \theta, \gamma, \lambda, \varphi, \delta$, and $\mu$, respectively.

The fixed effects approach controls for the omitted variables that differ between firms but are constant over time. It is necessary for the DID analysis. Furthermore, we try to explain the change in the firm's response before and after the shock. Hence, we use the difference between average post-period values and average pre-period values for the firm after removing changes explained by other factors. This entails the firm-specific intercept that is estimated via fixed effects. After conducting the Hausman test, we decide to use the fixed effects approach in the analysis.

We address the simultaneity issue between firm leverage and debt maturity by following the approach of Gatchev et al. (2010). We build a simultaneous equations model and use the lagged dependent variables to incorporate the intertemporal dependencies within variables. In the first step of the equations, we predict firm leverage via the lagged values of the debt maturity measure and the control variables. Year and firm fixed effects are included in the equation. Standard errors are clustered by the firm level.

$$
Z_{i, t}=\sigma+\tau * Y_{i, t-1}+\sum_{k=1}^{9} \phi_{k} * \text { Controls }_{i, t-1, k}+\varepsilon_{i, t}
$$

where the leverage measure is $\mathrm{Z}$; the debt maturity measure is $\mathrm{Y}$; the firm observation is $\mathrm{i}=1, \ldots, \mathrm{N}$; the entire period is $\mathrm{t}=1996, \ldots, 2009$; the number of control variables is $\mathrm{k}=1$, $\ldots, 9$; and the constant term and the coefficients of debt maturity measures, controls, and error term are $\sigma, \tau, \varphi$, and $\varepsilon$, respectively.

In the second step, we include the fitted leverage from the first step regression.

$$
\begin{aligned}
Y_{i, t}= & \alpha+\beta * X_{i, t}+\theta * \text { Post }_{i, t} * \text { Treatment }_{i, t}+\gamma * X_{i, t} * \text { Post }_{i, t} \\
& +\lambda * X_{i, t} * \text { Treatment }_{i, t}+\phi * X_{i, t} * \text { Post }_{i, t} * \text { Treatment }_{i, t}+\sum_{k=1}^{10} \delta_{k} * \text { Controls }_{i, t, k} \\
& +\omega * \hat{Z}_{i, t}+\mu_{i, t}
\end{aligned}
$$

where the debt maturity measure is $\mathrm{Y}$; the change in board independence measure is $\mathrm{X}$; the firm observation is $\mathrm{i}=1, \ldots, \mathrm{N}$; the entire period is $\mathrm{t}=1996, \ldots, 2009$; the number of control variables is $\mathrm{k}=1, \ldots, 10$; and the constant term and the coefficients of the change 
in board independence, treatment firms in the post-period, board independence changes in the post-period, treatment firms' board independence changes, treatment firms' board independence changes in the post-period, controls, the fitted leverage measure, and error term are $\alpha, \beta, \theta, \gamma, \lambda, \varphi, \delta, \omega$, and $\mu$, respectively.

\section{Main results and further analyses}

\subsection{Multivariate analysis}

Table 3 presents the main analysis for the relation between board independence changes and debt maturity. Consistent with the literature, the baseline model findings in Column I for Short-Term Ratio indicate that larger, more profitable, and high-growth firms with high cash holdings and high tangibility tend to have less short-maturity debt. Companies also match the maturities of their assets with their debt. The baseline estimates in Column II include $\Delta$ Board Independence. Its statistically insignificant coefficient implies that changes in board independence in general do not influence the maturity structure of debt. This finding is not surprising because this model does not differentiate between treatment and control firms throughout the years in our sample and, thus, it can only provide a general conclusion. In Column III, the model includes only the Post $*$ Treatment interaction term. The statistically insignificant baseline results suggest that the effect of the legislation overall on short-term debt is unclear. SOX has many provisions and not all of them are associated with internal board monitoring through which maturity structure should be affected. In order to observe the true impact of changes in internal monitoring on debt maturity, we need to consider $\Delta$ Board Independence along with Post ${ }^{*}$ Treatment in our main model.

Columns IV, VI and VIII of Table 3 give estimates of the main model, while Columns $\mathrm{V}$, VII and IX present the simultaneous equations model estimates with the fitted leverage measure. In Column IV of Table 3, $\Delta$ Board Independence alone does not have any explanatory power over debt maturity. This measure cannot provide a clear interpretation because it includes periods both before and after the amendment, as well as both treatment and control firms. Statistically significant and positive results for Post $*$ Treatment suggest that there is a trend of increase in short-term debt maturity for treatment firms after the event. $\Delta$ Board Independence $*$ Post and $\Delta$ Board Independence * Treatment cannot provide any statistically significant outcomes. $\Delta$ Board Independence $*$ Post $*$ Treatment is the main variable of interest and represents the changes in board independence for treatment firms after the amendment. Its negative and statistically significant estimates indicate that treatment firms have less short-maturity debt afterwards when there is a positive change in board independence. Specifically, in Column IV, the amount of debt maturing up to 1 year declines by $17.5 \%(=1.036 * 0.169)$ with a one-standard-deviation increase (about 17\%) in board independence after the legislation. The decline is $16.9 \%$, and we find it to be statistically significant via the fitted-leverage analysis shown in Column V. Considering the total magnitude of change, the sensitivity of short-term debt to board independence changes is still negative: it is $-0.992(=-0.068+0.085+0.027-1.036)$ for treatment firms after the shock. While control firms in the post-period have a sensitivity of short-term debt to board independence changes of $0.017(=-0.068+0.085)$, it is $-0.041(=-0.068+0.027)$ for treatment firms in the pre-period. Overall, the findings suggest that firms not complying with the board independence requirement prior to 2002 experience decreases in short-term 


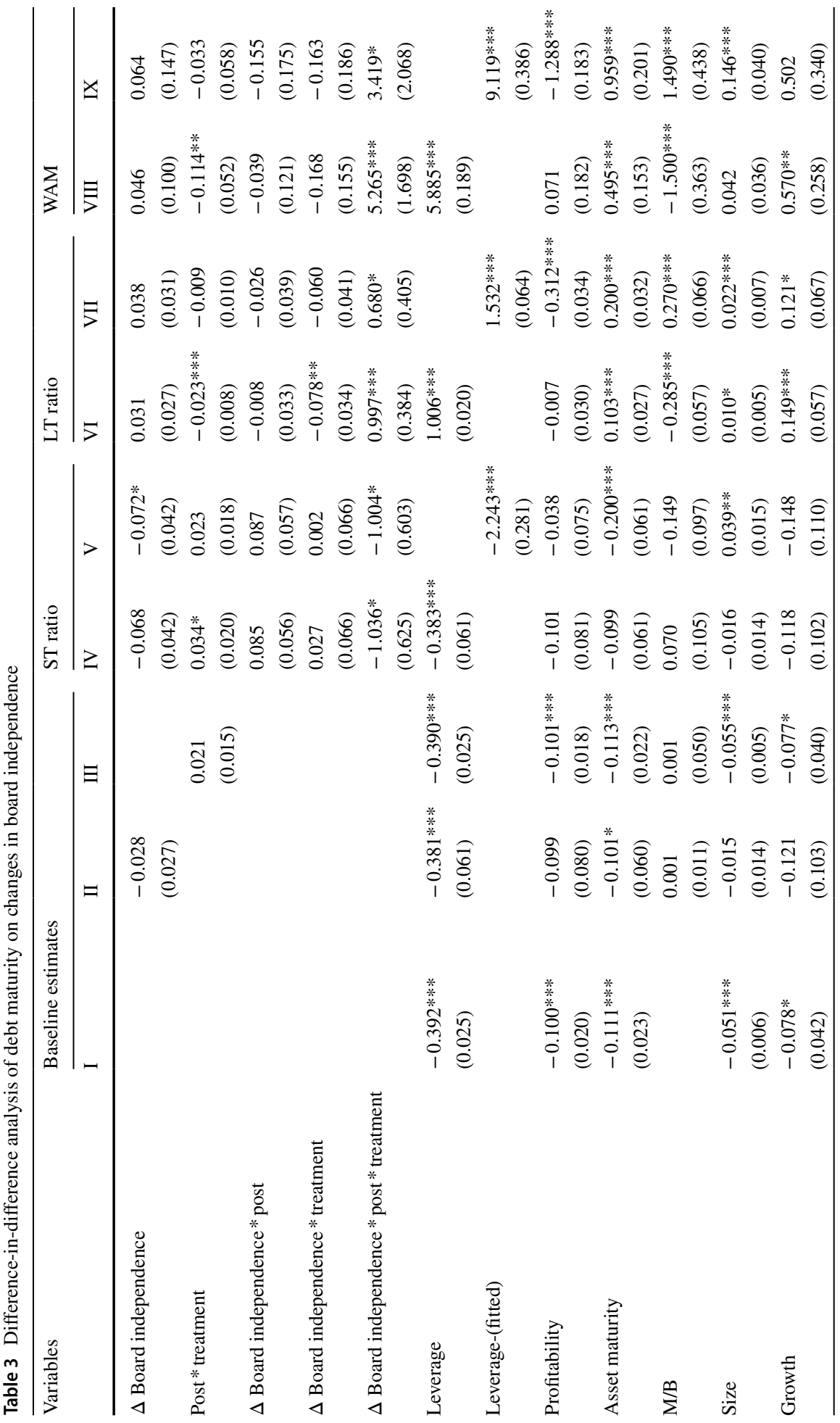




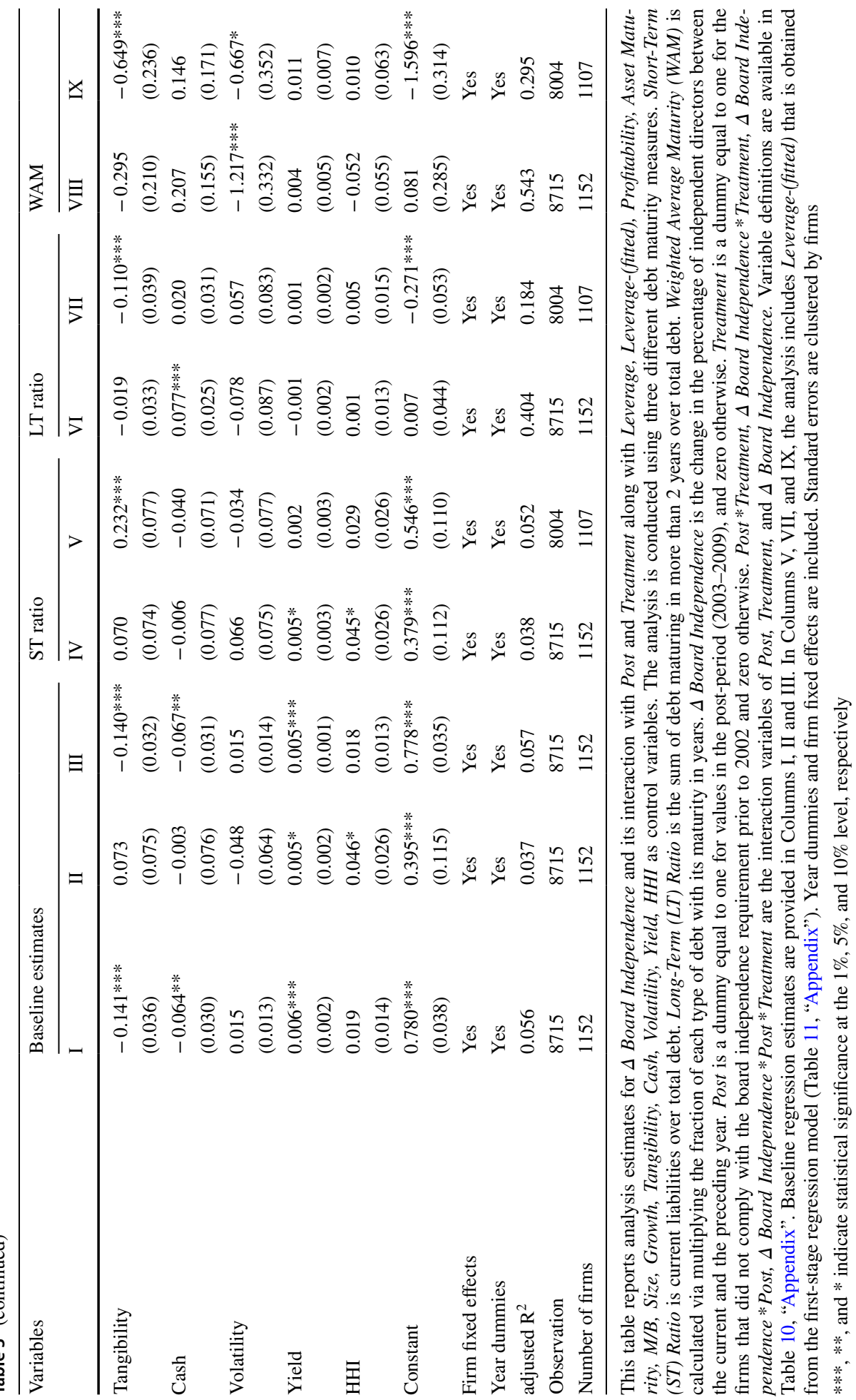


debt ratio afterwards, while companies not impacted by this requirement see a positive link between board independence and short-term debt. It is interesting to compare this result to the general trend in short-maturity debt. After the shock, short-term debt seems to increase by 0.034 for these treatment firms according to Post $*$ Treatment. But when the influence of an independent board is considered, the increasing trend in short-term debt ratio is reversed and short-term debt drops by 1.036. This shows the impact of board independence changes on the reduction in short-maturity debt.

Column VI of Table 3 shows the results for Long-Term Ratio. While the estimates for $\Delta$ Board Independence are statistically insignificant, the negative and significant estimates for Post $*$ Treatment imply that there is a trend of decrease in long-term debt maturity for treatment firms after the shock. $\Delta$ Board Independence $*$ Post cannot provide any statistically significant outcomes. $\Delta$ Board Independence *Treatment has significant and negative estimates. It suggests that treatment firms with increased board independence have less longmaturity debt when both the pre- and post-periods are considered together. Treatment firms before the legislation already had lower levels of long-term debt, which may account for the negative estimates for $\Delta$ Board Independence $*$ Treatment. Very significant and positive results for $\Delta$ Board Independence $*$ Post $*$ Treatment indicate that treatment firms increased the level of long-term debt after the shock when they had more independent boards. In Column VI, Long-Term Ratio increases by $16.9 \%(=0.997 * 0.169)$ when the board has $17 \%$ more independent directors for treatment firms in the post-period. That is a $9.97 \%$ increase in Long-Term Ratio when the board of 10 members has one additional independent director. The increase is $11.5 \%$ and also statistically significant via fitted-leverage analysis in Column VII. In terms of the total magnitude of change, the sensitivity of long-term debt to board independence changes is still positive: it is $0.942(=0.031-0.008-0.078+0.9$ 97) for treatment firms after the shock. While control firms in the post-period have a sensitivity of long-term debt to board independence changes of $0.023(=0.031-0.008)$, it is $-0.041(=0.031-0.078)$ for treatment firms in the pre-period. A comparison between the estimates of $\Delta$ Board Independence ${ }^{*}$ Post ${ }^{*}$ Treatment and Post ${ }^{*}$ Treatment reveals an interesting finding. The decreasing trend of $2.3 \%$ in long-term debt ratio is in fact reversed to a $16.9 \%$ increase when the influence of increased board independence (by one standard deviation) is considered. This shows the effect of board independence changes on the increase in long-maturity debt.

The results for Weighted Average Maturity are given in Column VIII of Table 3. $\Delta$ Board Independence, $\Delta$ Board Independence * Post and $\Delta$ Board Independence *Treatment do not have statistically significant estimates. On the contrary, negative and significant results for Post $*$ Treatment indicate that, for treatment firms after the event, there is a trend towards reduction in debt maturity. $\Delta$ Board Independence *Post*Treatment has significant and positive results at the $1 \%$ level. This suggests that treatment firms with positive changes in board independence have debt with longer maturity after the shock. In particular, Weighted Average Maturity jumps by $89 \%(=5.265 * 0.169)$ for treatment firms after the amendment when the board becomes more independent by $17 \%$. This is an increase of 10 months and 20 days. Similarly, the increase in Weighted Average Maturity is about $57.8 \%$, and we find it to be statistically significant via the fitted-leverage analysis shown in Column IX. Considering the total magnitude of change, the sensitivity of weighted average debt maturity to board independence changes is still positive and is $5.104(=0.0$ $46-0.039-0.168+5.265$ ) for treatment firms after the shock. While control firms in the post-period have a sensitivity of weighted average debt maturity to board independence changes of $0.007(=0.046-0.039)$, it is $-0.122(=0.046-0.168)$ for treatment firms in 
the pre-period. A comparison between the results for $\Delta$ Board Independence* $*$ Post $*$ Treatment and Post* Treatment unfolds a significant finding. For those treatment firms after the shock, debt maturity seems to decrease by about $11.4 \%$ according to Post $*$ Treatment. But, when the impact of an independent board is considered, the decreasing trend in weighted average maturity is reversed and debt maturity jumps by $89 \%$, on average, for one standard deviation increase in board independence. ${ }^{8}$

\subsection{Further analyses}

In further analyses, we repeat our main analysis, replacing $\Delta$ Board Independence with a dummy variable for the positive growth in board independence to examine the impact of board independence more directly. We show the results in Table 12 of the "Appendix", and they are consistent with our original findings. Non-co-opted board independence can be an effective mechanism to monitor the management. Hence, we conduct a separate analysis using the change in non-co-opted board independence instead. Following Coles et al. (2014), we construct $\Delta$ Non-Co-Opted Board Independence as the change between the current and the preceding year in the proportion of the board that consists of independent directors who were already on the board when the CEO assumed office. Statistically significant results in Table 13 of the "Appendix" support our hypothesis that more efficient internal monitoring is a substitute for external monitoring that leads to more long-term debt. In other analyses, we reflect the change in short-term debt relative to the change in long-term debt and obtain the results in Table IA.1 of the Internet Appendix, which are consistent with the original findings. Moreover, we repeat the analysis using the firms in the top quartile of the increase in board independence after the shock. We show more significant results for these firms in Table IA.1 of the Internet Appendix, which imply that stronger corporate governance through a more independent board influences lenders to choose long-maturity debt.

In additional analyses, we examine the potential effect of cash holdings further. High cash holdings may enhance repayment of debt to lenders in case of default, and longer-term contracts have higher probability of default. But firms and creditors may agree on longerterm debt if companies have high cash levels, regardless of the quality of corporate governance in those firms. Subsequently, our findings may not be robust for firms with a high level of cash holdings. Aside from controlling for cash in the main model, we consider only the firms in the top quartile of the Cash ratio. Further, we adjust the debt maturity measures for the cushion effect of cash on debt by multiplying them by " $1-$ Cash ratio". The results in Table 14 of the "Appendix" support our main results.

Blockholders can be considered as part of corporate governance because they may monitor managers using their voting power. Firms with good bond ratings signal their financial strength to creditors. These factors may have an influence on lenders while agreeing on the

\footnotetext{
${ }^{8}$ In untabulated analyses, we control for small cap firms as well as the residual leverage obtained from the first step of the simultaneous equations model. The original results remain robust. Further, we study financially unstable periods where dynamics are complex. Specifically, we focus on the 2000-2002 stock market crash due to the dot-com bubble and the 2007-2009 subprime mortgage crisis. We don't find sufficient evidence for the effect of improved corporate governance on debt maturity structure during financially troubled times. Several factors - such as increased default risk, financial distress, and the loss of credibility-may result in a low supply of credit in financial markets. Hence, even strong governance is insufficient to lead to increase in long-term debt.
} 
maturity of the debt contract. Similarly, the seniority of debt, as well as debt covenants, may impact the decision on debt maturity. Furthermore, financial constraints influence firms' ability to issue debt with various maturities. CEO tenure and overconfidence may affect a CEO's judgment while deciding on the maturity of debt. Moreover, CEO incentives may influence the debt maturity. Brockman et al. (2010) find a negative (positive) relation between CEO option deltas (vegas) and short-maturity debt. In further analyses, we control for these additional factors in our model. ${ }^{9}$ Rating is the firm's bond rating. Blockholders is the total percentage of the shares owned by the blockholders (i.e. shareholders with at least $5 \%$ of the firm's shares). Senior Debt is a dummy equal to one for firms with senior debt, and zero otherwise. Debt Covenants is a dummy equal to one for firms with strict debt covenants, and zero otherwise. Strict covenants have more protective terms for the items, such as dividend restrictions, excess cash flow, net income, and collaterals. We measure financial constraints through WW-Index and SA-Index, as introduced by Whited and Wu (2006) and Hadlock and Peirce (2010), respectively. ${ }^{10}$ As suggested by Hirshleifer et al. (2012), we control for CEO overconfidence through a dummy (CEO Overconfidence) that is equal to one if the CEO does not exercise an option when average moneyness is high. CEO Delta and $C E O$ Vega are the delta and the vega of the CEO option portfolio, calculated with the Black-Scholes formula's partial derivative with respect to stock price and stock volatility, respectively. In Table 15 of the "Appendix", statistically significant estimates for $\Delta$ Board Independence * Post * Treatment confirm the robustness of the original findings for these additional control variables.

The 14-year time interval in this study may be too long to observe the impact of the shock and include other factors that can create noise in our statistical estimates. Hence, we repeat the DID analysis for a shorter time interval and obtain robust results in Table IA.3 of the Internet Appendix. Additionally, we also examine the existence of other firm-related endogenous shocks or independent exogenous shocks that influence the relation between board independence changes and debt maturity. We conduct placebo tests in which we shift the time range of the study 2 years backward first, and then 2 years forward, keeping the main structure of the model the same. The insignificant findings in Table IA. 3 of the Internet Appendix signify that there are not any other trends or shocks but the SOX regulation leading to the SEC listing requirement that affect the change in board independence.

\subsubsection{The instrumental variable (IV) regression model}

We extend our analysis to address further any potential endogeneity issues associated with board composition. Following Duchin et al. (2010), we use the IV regression model. We construct Non-Compliant Dummy as the instrument that is equal to one if the firm did not comply with the requirement of a fully independent audit committee prior to 2000, and zero otherwise. The requirement of a fully independent audit committee is one of the first

\footnotetext{
9 Compared to single-segment firms, conglomerates may benefit more from efficient internal control over the management of multiple complex segments in several industries. We examine this aspect by studying conglomerate firms only. The results in Table IA. 2 of the Internet Appendix provide robust findings.

10 The results remain robust when we use KZ as the Kaplan-Zingales measure (1997), investment-cash flow sensitivity (Fazzari et al. 1988) and cash-cash flow sensitivity (Almeida et al. 2004) to identify financially constrained firms.
} 
Table 4 Instrumental variable regression of debt maturity on changes in board independence

\begin{tabular}{|c|c|c|c|c|}
\hline Variables & $\begin{array}{l}\text { First stage } \\
\text { I }\end{array}$ & $\begin{array}{l}\text { ST ratio } \\
\text { II }\end{array}$ & $\begin{array}{l}\text { LT ratio } \\
\text { III }\end{array}$ & $\begin{array}{l}\text { WAM } \\
\text { IV }\end{array}$ \\
\hline Non-compliant dummy & $\begin{array}{l}0.012 * * * \\
(0.003)\end{array}$ & & & \\
\hline$\Delta$ Board independence-(fitted) & & $\begin{array}{l}-1.673^{* *} \\
(0.656)\end{array}$ & $\begin{array}{l}1.303 * * * \\
(0.376)\end{array}$ & $\begin{array}{l}3.977 * * * \\
(1.335)\end{array}$ \\
\hline Leverage & $\begin{array}{l}0.015^{*} \\
(0.009)\end{array}$ & $\begin{array}{l}-0.366^{* * * *} \\
(0.023)\end{array}$ & $\begin{array}{l}0.756 * * * \\
(0.014)\end{array}$ & $\begin{array}{l}4.635 * * * \\
(0.058)\end{array}$ \\
\hline Asset maturity & $\begin{array}{l}0.081 \\
(0.101)\end{array}$ & $\begin{array}{l}-0.081^{* * * *} \\
(0.023)\end{array}$ & $\begin{array}{l}0.093 * * * \\
(0.015)\end{array}$ & $\begin{array}{l}0.385 * * * \\
(0.047)\end{array}$ \\
\hline Profitability & $\begin{array}{l}-0.002 \\
(0.015)\end{array}$ & $\begin{array}{l}-0.098 * * * \\
(0.018)\end{array}$ & $\begin{array}{l}0.043 * * * \\
(0.009)\end{array}$ & $\begin{array}{l}0.056 * * \\
(0.024)\end{array}$ \\
\hline $\mathrm{M} / \mathrm{B}$ & $\begin{array}{l}0.001 \\
(0.001)\end{array}$ & $\begin{array}{l}0.001 \\
(0.001)\end{array}$ & $\begin{array}{l}-0.003^{* * *} \\
(0.001)\end{array}$ & $\begin{array}{l}-0.007 * * * \\
(0.001)\end{array}$ \\
\hline Size & $\begin{array}{l}-0.002 * * \\
(0.001)\end{array}$ & $\begin{array}{l}-0.063 * * * \\
(0.005)\end{array}$ & $\begin{array}{l}0.047 * * * \\
(0.003)\end{array}$ & $\begin{array}{l}0.162 * * * \\
(0.009)\end{array}$ \\
\hline Growth & $\begin{array}{l}-0.039 \\
(0.030)\end{array}$ & $\begin{array}{l}-0.144 * * * \\
(0.048)\end{array}$ & $\begin{array}{l}0.198^{* * * *} \\
(0.031)\end{array}$ & $\begin{array}{l}0.681 * * * \\
(0.112)\end{array}$ \\
\hline Tangibility & $\begin{array}{l}0.013 \\
(0.008)\end{array}$ & $\begin{array}{l}-0.139 * * * \\
(0.034)\end{array}$ & $\begin{array}{l}0.043 * * \\
(0.020)\end{array}$ & $\begin{array}{l}0.196^{* * * *} \\
(0.074)\end{array}$ \\
\hline Cash & $\begin{array}{l}-0.003 \\
(0.008)\end{array}$ & $\begin{array}{l}-0.061^{* *} \\
(0.027)\end{array}$ & $\begin{array}{l}0.112 * * * \\
(0.015)\end{array}$ & $\begin{array}{l}0.315^{* * * *} \\
(0.035)\end{array}$ \\
\hline Volatility & $\begin{array}{l}-0.028 \\
(0.029)\end{array}$ & $\begin{array}{l}0.061 \\
(0.089)\end{array}$ & $\begin{array}{l}0.017 \\
(0.062)\end{array}$ & $\begin{array}{l}-0.036 \\
(0.330)\end{array}$ \\
\hline Yield & $\begin{array}{l}-0.014^{* * * *} \\
(0.003)\end{array}$ & $\begin{array}{l}-0.020^{* *} \\
(0.008)\end{array}$ & $\begin{array}{l}0.017 * * * \\
(0.005)\end{array}$ & $\begin{array}{l}0.053 * * * \\
(0.018)\end{array}$ \\
\hline HHI & $\begin{array}{l}-0.001 \\
(0.005)\end{array}$ & $\begin{array}{l}0.004 \\
(0.014)\end{array}$ & $\begin{array}{l}-0.007 \\
(0.008)\end{array}$ & $\begin{array}{l}-0.032 \\
(0.026)\end{array}$ \\
\hline Fixed effects & Yes & Yes & Yes & Yes \\
\hline Adjusted $\mathrm{R}^{2}$ & 0.091 & 0.202 & 0.082 & 0.088 \\
\hline Observation & 8715 & 8715 & 8715 & 8715 \\
\hline Weak instrument test & 19.61 & & & \\
\hline Under-identification test & 5.22 & & & \\
\hline
\end{tabular}

This table reports instrumental variable regression analysis estimates for $\Delta$ Board Independence-(fitted) and firm control variables. Column I presents the first-stage regression of $\Delta$ Board Independence on NonCompliant Dummy. Non-compliant Dummy is a dummy that is equal to one if the firm did not comply with the requirement of a fully independent audit committee prior to 2000. Columns II, III, and IV present the second-stage regression of Short-Term (ST) Ratio, Long-Term (LT) Ratio, and Weighted Average Maturity $(W A M)$ on $\Delta$ Board Independence-(fitted) values from the first-stage regression. Variable definitions are available in Table 10, "Appendix". Year dummies are included. Standard errors are clustered by firms

$* * *, * *$, and * indicate statistical significance at the $1 \%, 5 \%$, and $10 \%$ level, respectively. For weak instrument and under-identification tests, Cragg-Donald Wald and Anderson's canonical correlations likelihoodratio statistics are shown, respectively 
regulations approved by the NYSE and NASDAQ. Hence, firms that did not comply with this regulation are more likely to be non-compliant with the rule on board independence. Thus, Non-Compliant Dummy represents the treatment group in this IV model setup. Further, this regulatory change in audit committee would influence firms to change their board structure but should not affect the maturity structure of debt directly. Thus, we believe that Non-Compliant Dummy is a well-fit instrument for this analysis. In the first stage, we regress $\Delta$ Board Independence on Non-Compliant Dummy. In the second-stage regression, we use the fitted board independence changes from the first-stage regression as the main variable to explain the debt maturity measures. Year and firm fixed effects are included in the model along with the control variables. Standard errors are clustered at the firm level. To check for weak instruments and under-identification in our model, we conduct CraggDonald's Wald $F$ weak-instrument test and Anderson's canonical correlations likelihoodratio test. $F$ statistics of 19.61 and a Chi square of 5.22, respectively, imply that the instrument is not weak, canonical correlations are different from zero, and under-identification is not issue in our analyses. Over-identification is not a problem in the analyses because we have only one instrument in the model: Non-Compliant Dummy.

Table 4 presents the findings. In Column I, the estimate for Non-Compliant Dummy from the first-stage regression is statistically significant. In Column II, the negative relation between board independence changes and Short-Term Ratio persists. In particular, firms have $1.67 \%$ less short-term debt as board independence increases by $1 \%$. The findings in Columns III and IV suggest that the positive effect of board independence on long-term debt remains robust and statistically significant. When the board of 10 members has one additional independent director, Long-Term Ratio jumps by $13 \%$ and Weighted Average Maturity increases by $39.7 \%$, which is about 144 days. $^{11}$

\subsubsection{New debt issuance}

In our analyses, we use the total debt outstanding. The new debt issuance may provide a better understanding because it represents the immediate response by lenders to the changes in internal control through increased board independence. Hence, in further analyses, we construct the debt maturity measures using newly issued debt. We collect the data for new debt issuance mainly from Thomson Reuters SDC database, which includes new issues in debt capital markets. For completion of our dataset, we also compare the collected data to DealScan, TRACE database and Compustat items "Long-Term Debt Issuance" and "Current Debt Changes". For each firm-year, we include only the debt that is newly issued in that year for that firm. We repeat our main analysis using this refined dataset. Table 5 shows the findings. In Column I, consistent with the original results, treatment firms with increased board independence after the shock have less new short-maturity debt. In Columns II and III, statistically significant and positive estimates for Long-Term Ratio and Weighted Average Maturity indicate that the positive influence of improved

\footnotetext{
11 In untabulated analyses, we address the potential issue of sample selection bias. We construct a Heckman self-selection model and try to alleviate the concern that the decision to be a complaint firm prior to 2002 is under managerial discretion. We obtain supporting results consistent with our original findings.
} 
Table 5 difference-in-difference analysis via new debt issuance

\begin{tabular}{|c|c|c|c|}
\hline Variables & $\begin{array}{l}\text { ST ratio } \\
\text { I }\end{array}$ & $\begin{array}{l}\text { LT ratio } \\
\text { II }\end{array}$ & $\begin{array}{l}\text { WAM } \\
\text { III }\end{array}$ \\
\hline$\Delta$ Board independence & $\begin{array}{l}-0.126^{*} \\
(0.072)\end{array}$ & $\begin{array}{l}0.080 \\
(0.128)\end{array}$ & $\begin{array}{l}0.333 \\
(0.395)\end{array}$ \\
\hline Post $*$ treatment & $\begin{array}{l}-0.009 \\
(0.025)\end{array}$ & $\begin{array}{l}-0.003 \\
(0.025)\end{array}$ & $\begin{array}{l}0.008 \\
(0.067)\end{array}$ \\
\hline$\Delta$ Board independence $*$ post & $\begin{array}{l}0.083 \\
(0.114)\end{array}$ & $\begin{array}{l}-0.078 \\
(0.113)\end{array}$ & $\begin{array}{l}-0.244 \\
(0.348)\end{array}$ \\
\hline$\Delta$ Board independence $*$ treatment & $\begin{array}{l}0.298 \\
(0.385)\end{array}$ & $\begin{array}{l}-0.217^{*} \\
(0.131)\end{array}$ & $\begin{array}{l}-0.858^{* *} \\
(0.400)\end{array}$ \\
\hline$\Delta$ Board independence $*$ post $*$ treatment & $\begin{array}{l}-1.655^{*} \\
(1.004)\end{array}$ & $\begin{array}{l}0.580^{* *} \\
(0.286)\end{array}$ & $\begin{array}{l}1.701 * * \\
(0.766)\end{array}$ \\
\hline Leverage & $\begin{array}{l}-0.208^{*} \\
(0.115)\end{array}$ & $\begin{array}{l}-0.036 \\
(0.075)\end{array}$ & $\begin{array}{l}0.868^{* * * *} \\
(0.230)\end{array}$ \\
\hline Asset maturity & $\begin{array}{l}0.261 * * \\
(0.117)\end{array}$ & $\begin{array}{l}0.174 * * * \\
(0.067)\end{array}$ & $\begin{array}{l}0.473 * * \\
(0.223)\end{array}$ \\
\hline Profitability & $\begin{array}{l}-0.202 \\
(0.148)\end{array}$ & $\begin{array}{l}0.125 \\
(0.089)\end{array}$ & $\begin{array}{l}0.382 \\
(0.254)\end{array}$ \\
\hline $\mathrm{M} / \mathrm{B}$ & $\begin{array}{l}0.003 \\
(0.003)\end{array}$ & $\begin{array}{l}-0.003 \\
(0.002)\end{array}$ & $\begin{array}{l}-0.008 \\
(0.009)\end{array}$ \\
\hline Size & $\begin{array}{l}-0.023 \\
(0.031)\end{array}$ & $\begin{array}{l}-0.046^{* *} \\
(0.019)\end{array}$ & $\begin{array}{l}-0.210^{* * *} \\
(0.057)\end{array}$ \\
\hline Growth & $\begin{array}{l}-0.248 \\
(0.231)\end{array}$ & $\begin{array}{l}0.471 * * \\
(0.229)\end{array}$ & $\begin{array}{l}1.251 * * \\
(0.584)\end{array}$ \\
\hline Tangibility & $\begin{array}{l}0.130 \\
(0.165)\end{array}$ & $\begin{array}{l}-0.116 \\
(0.142)\end{array}$ & $\begin{array}{l}-0.109 \\
(0.382)\end{array}$ \\
\hline Cash & $\begin{array}{l}-0.096 \\
(0.192)\end{array}$ & $\begin{array}{l}0.008 \\
(0.087)\end{array}$ & $\begin{array}{l}-0.012 \\
(0.175)\end{array}$ \\
\hline Volatility & $\begin{array}{l}0.005 \\
(0.174)\end{array}$ & $\begin{array}{l}-0.153 \\
(0.104)\end{array}$ & $\begin{array}{l}-0.659 * \\
(0.345)\end{array}$ \\
\hline Yield & $\begin{array}{l}0.011^{* * *} \\
(0.004)\end{array}$ & $\begin{array}{l}-0.001 \\
(0.003)\end{array}$ & $\begin{array}{l}0.017 * * \\
(0.007)\end{array}$ \\
\hline HHI & $\begin{array}{l}0.126^{*} \\
(0.076)\end{array}$ & $\begin{array}{l}-0.069^{*} \\
(0.041)\end{array}$ & $\begin{array}{l}-0.106 \\
(0.116)\end{array}$ \\
\hline Year and firm fixed effects & Yes & Yes & Yes \\
\hline Adjusted $\mathrm{R}^{2}$ & 0.047 & 0.077 & 0.074 \\
\hline Observation & 7123 & 7123 & 7123 \\
\hline
\end{tabular}

This table reports analysis estimates for $\Delta$ Board Independence and its interaction with Post and Treatment along with Leverage, Leverage-(fitted), Profitability, Asset Maturity, M/B, Size, Growth, Tangibility, Cash, Volatility, Yield, HHI as control variables. The analysis is conducted using the new debt issuance only. Short-Term (ST) Ratio, Long-Term (LT) Ratio, and Weighted Average Maturity (WAM) are the dependent variables. Post *Treatment, $\Delta$ Board Independence *Treatment, $\Delta$ Board Independence * Post, $\Delta$ Board Independence *Post $*$ Treatment are the interaction variables of Post, Treatment, and $\Delta$ Board Independence. Variable definitions are available in Table 10, "Appendix". Year and firm fixed effects are included. Standard errors are clustered by firms

$* * *, * *$, and $*$ indicate significance at the $1 \%, 5 \%$, and $10 \%$ level, respectively 
Table 6 Difference-in-difference analysis for the cases with the need for internal monitoring

\begin{tabular}{|c|c|c|c|c|c|c|}
\hline \multirow[t]{3}{*}{ Variables } & \multicolumn{3}{|l|}{ CEO duality } & \multicolumn{3}{|c|}{ GIM index $>$ median } \\
\hline & ST ratio & LT ratio & WAM & ST ratio & LT ratio & WAM \\
\hline & I & II & III & IV & $\mathrm{V}$ & VI \\
\hline \multicolumn{7}{|c|}{ Panel A: Cases with CEO duality and high GIM index } \\
\hline \multirow{2}{*}{$\begin{array}{l}\Delta \text { Board independ- } \\
\text { ence } * \text { post } * \text { treatment }\end{array}$} & $-0.235^{*}$ & $0.823^{*}$ & $4.558 * * *$ & $-1.187^{*}$ & $1.016^{* *}$ & $6.084 * * *$ \\
\hline & $(0.138)$ & $(0.491)$ & $(1.704)$ & $(0.712)$ & $(0.472)$ & $(1.932)$ \\
\hline \multirow[t]{2}{*}{ Constant } & $0.124 * * *$ & 0.026 & 0.144 & $0.143 * * *$ & 0.015 & 0.092 \\
\hline & $(0.017)$ & $(0.057)$ & $(0.334)$ & $(0.022)$ & $(0.063)$ & $(0.266)$ \\
\hline Interaction terms & Yes & Yes & Yes & Yes & Yes & Yes \\
\hline Firm controls & Yes & Yes & Yes & Yes & Yes & Yes \\
\hline Year and firm FE & Yes & Yes & Yes & Yes & Yes & Yes \\
\hline Adjusted $\mathrm{R}^{2}$ & 0.030 & 0.399 & 0.531 & 0.013 & 0.418 & 0.554 \\
\hline Observation & 4954 & 4954 & 4954 & 5143 & 5143 & 5143 \\
\hline \multirow[t]{3}{*}{ Variables } & \multicolumn{3}{|c|}{ Straight debt only } & \multicolumn{3}{|c|}{ Less strict (or no) covenants } \\
\hline & ST ratio & LT ratio & WAM & ST ratio & LT ratio & WAM \\
\hline & $\mathrm{I}$ & II & III & IV & $\mathrm{V}$ & VI \\
\hline \multicolumn{7}{|c|}{ Panel B: Cases with straight debt and less strict debt covenants } \\
\hline \multirow{2}{*}{$\begin{array}{l}\Delta \text { Board independ- } \\
\text { ence *post * treatment }\end{array}$} & $-1.143^{*}$ & $1.092 * *$ & $4.730 * * *$ & $-1.491 *$ & $0.922 *$ & $4.693^{*}$ \\
\hline & $(0.657)$ & $(0.450)$ & $(1.620)$ & $(0.892)$ & $(0.546)$ & $(2.508)$ \\
\hline \multirow[t]{2}{*}{ Constant } & $0.214 * * *$ & 0.007 & 0.207 & $0.410^{* * *}$ & $0.156^{* *}$ & $0.563^{* *}$ \\
\hline & $(0.014)$ & $(0.064)$ & $(0.257)$ & $(0.147)$ & $(0.061)$ & $(0.271)$ \\
\hline Interaction terms & Yes & Yes & Yes & Yes & Yes & Yes \\
\hline Firm controls & Yes & Yes & Yes & Yes & Yes & Yes \\
\hline Year and firm FE & Yes & Yes & Yes & Yes & Yes & Yes \\
\hline Adjusted $\mathrm{R}^{2}$ & 0.055 & 0.401 & 0.548 & 0.040 & 0.401 & 0.490 \\
\hline Observation & 5358 & 5358 & 5358 & 3129 & 3129 & 3129 \\
\hline \multirow[t]{3}{*}{ Variables } & \multicolumn{3}{|c|}{ CEO opportunism (top quintile) } & \multicolumn{3}{|c|}{ High real earnings management } \\
\hline & ST ratio & LT ratio & WAM & ST ratio & LT ratio & WAM \\
\hline & $\mathrm{I}$ & II & III & IV & $\mathrm{V}$ & VI \\
\hline \multicolumn{7}{|c|}{ Panel C: Cases with high discretionary accruals and high real earnings management } \\
\hline \multirow{2}{*}{$\begin{array}{l}\Delta \text { Board independ- } \\
\text { ence } * \text { post } * \text { treatment }\end{array}$} & $-4.995 * * *$ & $3.279 * * *$ & $8.066^{*}$ & $-6.771^{*}$ & $1.299 *$ & $6.017 * *$ \\
\hline & $(1.457)$ & $(1.201)$ & $(4.570)$ & $(4.008)$ & $(0.746)$ & $(2.772)$ \\
\hline \multirow[t]{2}{*}{ Constant } & $0.519 * *$ & -0.140 & -0.486 & $0.422 * * *$ & -0.131 & -0.086 \\
\hline & $(0.225)$ & $(0.143)$ & $(0.492)$ & $(0.087)$ & $(0.109)$ & $(0.410)$ \\
\hline Interaction terms & Yes & Yes & Yes & Yes & Yes & Yes \\
\hline Firm controls & Yes & Yes & Yes & Yes & Yes & Yes \\
\hline Year and firm FE & Yes & Yes & Yes & Yes & Yes & Yes \\
\hline Adjusted $\mathrm{R}^{2}$ & 0.094 & 0.537 & 0.578 & 0.097 & 0.386 & 0.537 \\
\hline Observation & 1102 & 1102 & 1102 & 2270 & 2270 & 2270 \\
\hline
\end{tabular}


Table 6 (continued)

\begin{tabular}{|c|c|c|c|c|c|c|}
\hline \multirow[t]{3}{*}{ Variables } & \multicolumn{3}{|c|}{ Intangibility (above median) } & \multicolumn{3}{|c|}{ Free cash flow (above median) } \\
\hline & ST ratio & LT ratio & WAM & ST ratio & LT ratio & WAM \\
\hline & I & II & III & IV & $\mathrm{V}$ & VI \\
\hline \multicolumn{7}{|c|}{ Panel D: Cases with high intangibility and high free cash flow ratio } \\
\hline $\begin{array}{l}\Delta \text { Board independ- } \\
\text { ence* post* treat- } \\
\text { ment }\end{array}$ & $\begin{array}{l}-1.193^{*} \\
(0.697)\end{array}$ & $\begin{array}{l}1.249 * * * \\
(0.462)\end{array}$ & $\begin{array}{l}6.218 * * * \\
(1.774)\end{array}$ & $\begin{array}{l}-1.168^{* *} \\
(0.577)\end{array}$ & $\begin{array}{l}0.990 * * * \\
(0.371)\end{array}$ & $\begin{array}{l}4.771 * * * \\
(1.560)\end{array}$ \\
\hline Constant & $\begin{array}{l}0.229 * * * \\
(0.030)\end{array}$ & $\begin{array}{l}-0.031 \\
(0.048)\end{array}$ & $\begin{array}{l}-0.033 \\
(0.178)\end{array}$ & $\begin{array}{l}0.376 * * * \\
(0.093)\end{array}$ & $\begin{array}{l}-0.018 \\
(0.041)\end{array}$ & $\begin{array}{l}0.027 \\
(0.241)\end{array}$ \\
\hline Interaction terms & Yes & Yes & Yes & Yes & Yes & Yes \\
\hline Firm controls & Yes & Yes & Yes & Yes & Yes & Yes \\
\hline Year and firm FE & Yes & Yes & Yes & Yes & Yes & Yes \\
\hline Adjusted $\mathrm{R}^{2}$ & 0.035 & 0.367 & 0.512 & 0.044 & 0.411 & 0.540 \\
\hline \multirow[t]{2}{*}{ Observation } & 4893 & 4893 & 4893 & 5199 & 5199 & 5199 \\
\hline & & \multicolumn{5}{|c|}{ No majority blockholders } \\
\hline \multirow{2}{*}{\multicolumn{2}{|c|}{ Variables }} & \multicolumn{2}{|l|}{ ST ratio } & \multicolumn{2}{|l|}{ LT ratio } & WAM \\
\hline & & \multicolumn{2}{|l|}{ I } & \multicolumn{2}{|l|}{ II } & III \\
\hline \multicolumn{7}{|c|}{ Panel E: Case without majority blockholders } \\
\hline \multicolumn{2}{|c|}{$\begin{array}{l}\Delta \text { Board independence } * \text { post } * \text { treat- } \\
\text { ment }\end{array}$} & \multicolumn{2}{|l|}{$\begin{array}{l}-1.029^{*} \\
(0.598)\end{array}$} & \multicolumn{2}{|l|}{$\begin{array}{l}1.001 * * * \\
(0.389)\end{array}$} & $\begin{array}{l}5.129 * * * \\
(1.600)\end{array}$ \\
\hline \multicolumn{2}{|l|}{ Constant } & \multicolumn{2}{|l|}{$\begin{array}{l}0.305 * * * \\
(0.015)\end{array}$} & \multicolumn{2}{|l|}{$\begin{array}{l}0.016 \\
(0.041)\end{array}$} & $\begin{array}{l}-0.009 \\
(0.274)\end{array}$ \\
\hline \multicolumn{2}{|l|}{ Interaction terms } & \multicolumn{2}{|l|}{ Yes } & \multicolumn{2}{|l|}{ Yes } & Yes \\
\hline \multicolumn{2}{|l|}{ Firm controls } & \multicolumn{2}{|l|}{ Yes } & \multicolumn{2}{|l|}{ Yes } & Yes \\
\hline \multicolumn{2}{|l|}{ Year and firm FE } & \multicolumn{2}{|l|}{ Yes } & \multicolumn{2}{|l|}{ Yes } & Yes \\
\hline \multicolumn{2}{|l|}{ Adjusted $\mathrm{R}^{2}$} & \multicolumn{2}{|l|}{0.085} & \multicolumn{2}{|l|}{0.409} & 0.549 \\
\hline \multicolumn{2}{|l|}{ Observation } & \multicolumn{2}{|l|}{7432} & \multicolumn{2}{|l|}{7432} & 7432 \\
\hline
\end{tabular}

This table reports analysis estimates for the triple interaction term for the cases with the need for internal monitoring. In panel A, the analysis is conducted for the firms with the CEO being the chair of the board, as well as, the companies with the GIM Index above the median value. In Panel B, the analysis is repeated for the firms without any convertible debt, as well as, the companies with less strict (or without) debt covenants. In Panel C, the test is conducted for the firms with discretionary accruals value in the top quintile, as well as, companies with high real earnings management. In Panel D, the test is repeated for the firms with intangibility and free cash flow ratio above the sample median values, respectively. In Panel E, the analysis is conducted for the firms without majority blockholders. Intangibility is intangibles over total assets. Free cash flow ratio is free cash flows over sales. Short-Term (ST) Ratio, Long-Term (LT) Ratio, and Weighted Average Maturity $(W A M)$ are the dependent variables. $\triangle$ Board Independence $*$ Post *Treatment is the triple interaction term. Variable definitions are available in Table 10, "Appendix". Year dummies, firm controls and firm fixed effects are included. Standard errors are clustered at the firm level $* * *, * *$, and $*$ indicate statistical significance at the $1 \%, 5 \%$, and $10 \%$ level, respectively 
corporate governance through increased board independence on long-term debt persists in this robustness test.

\subsubsection{Need for internal monitoring}

In further analyses, we examine cases where there is a greater need for internal control over managers. In particular, we consider the entrenchment of firms with CEO duality (Feng et al. 2007), a GIM index above median value, discretionary accruals in the top quintile range, and high real earnings management (REM). ${ }^{12}$ We also study companies with only straight debt, and less strict or without-debt covenants. Furthermore, we examine firms without majority blockholders and companies with intangibility and free cash flow ratios above the sample median values. We expect stronger results for these specific firms because the improvement in corporate governance through increased board independence should be more appreciated by creditors in such cases, which engender more severe agency costs e.g., Green (1984), Haugen and Senbet (1981). Table 6 shows the findings. We obtain statistically significant, similar or even stronger results. Specifically, treatment firms with high discretionary accruals have $55.4 \%(=3.279 * 0.169)$ more long-maturity debt when board independence increases by one standard deviation (17\%) after the event. Likewise, the increase in long-term debt is about $21.9 \%, 13.9 \%, 17.2 \%, 18.5 \%, 15.6 \%, 21.1 \%, 16.8 \%$ and $17 \%$ for firms with high real earnings management, the CEO duality problem, a high GIM index, straight debt only, less strict debt covenants, high intangibility, high free cash flow, and no majority blockholders, respectively. In general, these results are economically more significant than the original finding of $16.9 \%$ for long-term debt.

\subsubsection{Alternative channels for internal monitoring}

In this paper, we proxy internal monitoring by the regulatory changes in board independence. However, the literature suggests other channels for internal monitoring as well. Husson et al. (2001) argue that board size and incentive compensation to directors can act as an internal monitoring mechanism. Cremers and Nair (2005) discuss that blockholders in firms can monitor the management internally. Guo and Masulis (2015) show that nominating committee full independence can lead to rigorous CEO monitoring and discipline. To examine any potential influence of these channels on our main results and test the robustness of our findings, we construct the following four internal monitoring measures. ${ }^{13}$ Blockholders is the total percentage of shares owned by the blockholders;

\footnotetext{
12 Following Roychowdhury (2006) and Enomoto et al. (2015), we use the abnormal values of reduction in discretionary expenditures_-including selling, advertising, R\&D, and general and administrative expenses (SGA) - to identify high real earnings management. We consider the firms in the lowest quintile of abnormal SGA values because the CEO in those firms decides the largest cuts (negative difference from "normal values") in those expenses beyond an optimal level. In untabulated analyses, we find supporting results using production cost and cash flow from operations to identify REM.

13 We acknowledge that board size and board incentive pay can be endogenously determined in the firm. Relying on Husson et al. (2001), we only provide suggestive and alternative ways for internal monitoring without making a strong claim when we use these two measures. However, the latter two alternative mechanisms of internal monitoring are implemented externally and should be subjected less to firm endogeneity. Mandated by SEC in 2003, NYSE- and NASDAQ-listed firms shall have a nominating committee with only independent directors. Furthermore, the percentage of blockholding shares in the firm depends on the decision by external investors regarding their investment strategies.
} 
Table 7 Analyses with alternative measures for internal monitoring

\begin{tabular}{|c|c|c|c|c|c|c|}
\hline \multirow[t]{3}{*}{ Variables } & \multicolumn{3}{|c|}{ Blockholder ownership } & \multicolumn{3}{|l|}{ Board size } \\
\hline & ST ratio & LT ratio & WAM & ST ratio & LT ratio & WAM \\
\hline & I & II & III & IV & $\mathrm{V}$ & VI \\
\hline \multicolumn{7}{|c|}{ Panel A: Tests for internal monitoring via blockholder ownership and board size } \\
\hline Blockholders * post * treatment & $\begin{array}{l}0.067 \\
(0.101)\end{array}$ & $\begin{array}{l}-0.067 \\
(0.046)\end{array}$ & $\begin{array}{l}-0.218 \\
(0.230)\end{array}$ & & & \\
\hline $\operatorname{Ln}($ BoardSize $) *$ post $*$ treatment & & & & $\begin{array}{l}-0.116 \\
(0.071)\end{array}$ & $\begin{array}{l}-0.029 \\
(0.024)\end{array}$ & $\begin{array}{l}0.011 \\
(0.139)\end{array}$ \\
\hline Constant & $\begin{array}{l}0.767 * * * \\
(0.059)\end{array}$ & $\begin{array}{l}-0.167 * * * \\
(0.021)\end{array}$ & $\begin{array}{l}-0.538^{* * *} \\
(0.101)\end{array}$ & $\begin{array}{l}0.478 * * * \\
(0.114)\end{array}$ & $\begin{array}{l}-0.092^{*} \\
(0.047)\end{array}$ & $\begin{array}{l}-0.281 \\
(0.280)\end{array}$ \\
\hline Interaction terms & Yes & Yes & Yes & Yes & Yes & Yes \\
\hline Firm controls & Yes & Yes & Yes & Yes & Yes & Yes \\
\hline Year and firm FE & Yes & Yes & Yes & Yes & Yes & Yes \\
\hline Adjusted $\mathrm{R}^{2}$ & 0.048 & 0.316 & 0.491 & 0.051 & 0.426 & 0.555 \\
\hline Observation & 8715 & 8715 & 8715 & 8715 & 8715 & 8715 \\
\hline \multirow[t]{3}{*}{ Variables } & \multicolumn{3}{|c|}{ Nominating committee } & \multicolumn{3}{|c|}{ Board incentive pay } \\
\hline & ST ratio & LT ratio & WAM & ST ratio & LT ratio & WAM \\
\hline & I & II & III & IV & V & VI \\
\hline
\end{tabular}

Panel B: Tests for internal monitoring via nominating committee and board incentive pay

\begin{tabular}{|c|c|c|c|c|c|c|}
\hline $\begin{array}{l}\text { NominatingFull } * \text { post } * \text { treat- } \\
\text { ment }\end{array}$ & $\begin{array}{l}-0.015 \\
(0.035)\end{array}$ & $\begin{array}{l}0.031 \\
(0.019)\end{array}$ & $\begin{array}{l}0.020 \\
(0.098)\end{array}$ & & & \\
\hline $\begin{array}{l}\text { BoardIncentive- } \\
\text { Pay* post } * \text { treatment }\end{array}$ & & & & $\begin{array}{l}-0.524 \\
(0.447)\end{array}$ & $\begin{array}{l}0.363 \\
(0.232)\end{array}$ & $\begin{array}{l}1.040 \\
(1.102)\end{array}$ \\
\hline Constant & $\begin{array}{l}0.424 * * * \\
(0.097)\end{array}$ & $\begin{array}{l}-0.038 \\
(0.037)\end{array}$ & $\begin{array}{l}-0.134 \\
(0.243)\end{array}$ & $\begin{array}{l}0.776 * * * \\
(0.038)\end{array}$ & $\begin{array}{l}-0.212^{* * *} \\
(0.015)\end{array}$ & $\begin{array}{l}-0.673^{* * *} \\
(0.070)\end{array}$ \\
\hline Interaction terms & Yes & Yes & Yes & Yes & Yes & Yes \\
\hline Firm controls & Yes & Yes & Yes & Yes & Yes & Yes \\
\hline Year and firm FE & Yes & Yes & Yes & Yes & Yes & Yes \\
\hline Adjusted $\mathrm{R}^{2}$ & 0.048 & 0.426 & 0.555 & 0.057 & 0.319 & 0.499 \\
\hline Observation & 8715 & 8715 & 8715 & 8715 & 8715 & 8715 \\
\hline
\end{tabular}

This table reports analysis estimates for the interaction of Post and Treatment with variables representing internal monitoring. Four alternative internal monitoring measures are considered. In panel A, the analysis is conducted using Blockholders as the total percentage of shares owned by the blockholders, and NominatingFull as a dummy for the firms with fully independent nominating committee. In Panel B, the analysis is repeated using $\operatorname{Ln}$ (BoardSize) as the natural logarithm of board size, and BoardIncentivePay as the total $\$$ amount (in thousands) of incentive pay to all directors in the board. Short-Term (ST) Ratio, LongTerm (LT) Ratio, and Weighted Average Maturity (WAM) are the dependent variables. BoardIncentivePay *Post*Treatment, NominatingFull *Post*Treatment, Ln(BoardSize)*Post*Treatment, and Blockholders $*$ Post $*$ Treatment are the interaction variables of BoardIncentivePay, NominatingFull, Ln(BoardSize), Blockholders, Post, and Treatment. Variable definitions are available in Table 10, "Appendix". Year dummies, firm controls and firm fixed effects are included. Standard errors are clustered at the firm level $* * *, * *$, and * indicate statistical significance at the $1 \%, 5 \%$, and $10 \%$ level, respectively 
Table 8 Difference-in-difference analysis with SOX 404 exempt and small firms

\begin{tabular}{llll}
\hline Variables & ST ratio & LT ratio & WAM \\
& I & II & III \\
\hline
\end{tabular}

Panel A: Analysis with firms exempt from SOX Section 404

\begin{tabular}{|c|c|c|c|}
\hline$\Delta$ Board independence & $\begin{array}{l}-0.055 \\
(0.044)\end{array}$ & $\begin{array}{l}0.108 \\
(0.098)\end{array}$ & $\begin{array}{l}0.021 \\
(0.281)\end{array}$ \\
\hline Post $*$ treatment & $\begin{array}{l}0.038 \\
(0.024)\end{array}$ & $\begin{array}{l}-0.155^{* *} \\
(0.063)\end{array}$ & $\begin{array}{l}-0.226 \\
(0.154)\end{array}$ \\
\hline$\Delta$ Board independence $*$ post & $\begin{array}{l}0.082 \\
(0.088)\end{array}$ & $\begin{array}{l}-0.482^{*} \\
(0.250)\end{array}$ & $\begin{array}{l}-0.495 \\
(0.609)\end{array}$ \\
\hline$\Delta$ Board independence $*$ treatment & $\begin{array}{l}-0.009 \\
(0.062)\end{array}$ & $\begin{array}{l}-0.285^{* *} \\
(0.133)\end{array}$ & $\begin{array}{l}-0.425 \\
(0.382)\end{array}$ \\
\hline$\Delta$ Board independence $*$ post $*$ treatment & $\begin{array}{l}-1.760 * \\
(1.054)\end{array}$ & $\begin{array}{l}7.171 * \\
(3.834)\end{array}$ & $\begin{array}{l}15.630 * \\
(9.288)\end{array}$ \\
\hline Firm controls & Yes & Yes & Yes \\
\hline Year and firm fixed effects & Yes & Yes & Yes \\
\hline Adjusted $\mathrm{R}^{2}$ & 0.101 & 0.328 & 0.446 \\
\hline Observation & 1040 & 1040 & 1040 \\
\hline \multicolumn{4}{|c|}{ Panel B: Analysis with small firms (bottom quartile) } \\
\hline$\Delta$ Board independence & $\begin{array}{l}-0.123^{* *} \\
(0.059)\end{array}$ & $\begin{array}{l}0.046 \\
(0.067)\end{array}$ & $\begin{array}{l}0.101 \\
(0.311)\end{array}$ \\
\hline Post $*$ treatment & $\begin{array}{l}0.046^{* *} \\
(0.019)\end{array}$ & $\begin{array}{l}-0.125^{* *} \\
(0.052)\end{array}$ & $\begin{array}{l}-0.314^{* * *} \\
(0.106)\end{array}$ \\
\hline$\Delta$ Board independence $*$ post & $\begin{array}{l}0.157 * * \\
(0.074)\end{array}$ & $\begin{array}{l}0.026 \\
(0.105)\end{array}$ & $\begin{array}{l}-0.512 \\
(0.421)\end{array}$ \\
\hline$\Delta$ Board independence $*$ treatment & $\begin{array}{l}0.047 \\
(0.076)\end{array}$ & $\begin{array}{l}-0.300^{* *} \\
(0.119)\end{array}$ & $\begin{array}{l}-0.427 \\
(0.388)\end{array}$ \\
\hline$\Delta$ Board independence $*$ post $*$ treatment & $\begin{array}{l}-1.180^{*} \\
(0.668)\end{array}$ & $\begin{array}{l}3.202 * * \\
(1.583)\end{array}$ & $\begin{array}{l}13.630 * * \\
(5.554)\end{array}$ \\
\hline Firm controls & Yes & Yes & Yes \\
\hline Year and firm fixed effects & Yes & Yes & Yes \\
\hline Adjusted $\mathrm{R}^{2}$ & 0.127 & 0.354 & 0.580 \\
\hline Observation & 1891 & 1891 & 1891 \\
\hline
\end{tabular}

This table reports analysis estimates for $\Delta$ Board Independence and its interaction with Post and Treatment. In Panel A, the analysis is repeated for the firms that are exempted from SOX Section 404. In Panel B, the analysis is conducted using small firms in the bottom quartile of firm size. Short-Term (ST) Ratio, LongTerm (LT) Ratio, and Weighted Average Maturity (WAM) are the dependent variables. Post $*$ Treatment, $\Delta$ Board Independence *Treatment, $\Delta$ Board Independence *Post, $\Delta$ Board Independence * Post*Treatment are the interaction variables of Post, Treatment, and $\Delta$ Board Independence. Variable definitions are available in Table 10, "Appendix". Year dummies, firm controls, and firm fixed effects are included. Standard errors are clustered by firms

$* * *, * *$, and $*$ indicate statistical significance at the $1 \%, 5 \%$, and $10 \%$ level, respectively

NominatingFull is a dummy for the firms with fully independent nominating committees; Ln(BoardSize) is the natural logarithm of board size; BoardIncentivePay is the total \$ amount (in thousands) of incentive pay to all directors in the board. First, we include these 
monitoring measures as controls in the main model. Table IA.4 in the Internet Appendix shows that our original results remain robust to controlling for these additional monitoring channels. Then, we replace $\Delta$ Board Independence with Blockholders, Ln(BoardSize), NominatingFull, and BoardIncentivePay, and repeat the main analysis in Eq. (1) for each of these measures. Statistically insignificant results in Table 7 confirm that other potential channels for internal monitoring cannot explain our results in this paper.

\subsubsection{SOX Section 404 and firm size}

SOX brings several mandatory governance reforms, like Section 404. This mandates that the management of public companies must establish internal controls and procedures for financial reporting. They also have to document and test those controls to ensure their effectiveness. Some may argue that, like an increase in board independence, SOX 404 will also improve governance. Hence, any change in the governance may come through two self-reinforcing channels: better reporting of internal controls and more independent boards. To address this issue and disentangle the effect of increased board independence from the influence of SOX 404, we use a sub-sample of small firms that did not have to comply with SOX 404. Companies with less than $\$ 75$ million in public float are exempted from SOX 404 requirements. Additionally, we check that none of these firms has auditor reports on internal control. Focusing only on these firms should provide a clearer channel to observe the impact of an increase in board independence on debt maturity. Inspired by the SOX 404 exemption criterion, we further examine only very small firms. We use the companies in the bottom quartile of size and control for any potential impact of firm size on the maturity structure of debt.

Table 8 presents the findings. In Panel A, the statistically significant estimates for $\Delta$ Board Independence *Post ${ }^{*}$ Treatment are even stronger than our original results. In particular, treatment firms exempt from SOX 404 have 1.76\% less short-term debt and $7.17 \%$ more long-term debt when their board independence increases by $1 \%$ in the post-period. Their weighted average debt maturity is about 57 days $(=15.630 * 1 \% * 365)$. These results imply that SOX 404 does not derive our findings in this paper. The significant findings in Panel B also confirm that increased board independence leads to more (less) long-term (short-term) debt in very small firms.

\subsubsection{Auditors' liability exposure}

SOX was enacted as a reaction to the failure of Enron's auditors. As Enron's board was dominated by a powerful CEO, the primary emphasis of SOX is on increasing board independence. However, auditors' exposure to liability also increased after SOX. Hence, we need to examine whether our results might be due to an increase in auditors' liability rather than increased board independence. Following Simunic (1980) and Evans and Schwartz (2014), we construct four additional variables representing increased auditors' liability. Fee is audit-related fees over total assets. Auditor is a dummy equal to one for firms with a large auditor. Audited is a dummy equal to one for firms with a completed auditor's review of financial statements. Inadequate is a dummy equal to one if the auditor finds the firm's internal control inadequate, and zero otherwise. We repeat the main analysis replacing $\Delta$ Board Independence with these new variables. Table 9 presents the findings. The statistically insignificant results imply that an increase in auditors' liability is not significant in explaining the corporate debt maturity structure after the regulatory change. 
Table 9 Difference-in-difference analysis for auditors' liability exposure

\begin{tabular}{|c|c|c|c|c|c|c|}
\hline \multirow[t]{3}{*}{ Variables } & \multicolumn{3}{|c|}{ Audit fees } & \multicolumn{3}{|c|}{ Large auditors } \\
\hline & ST ratio & LT ratio & WAM & ST ratio & LT ratio & WAM \\
\hline & I & II & III & IV & $\mathrm{V}$ & VI \\
\hline \multicolumn{7}{|c|}{ Panel A: Tests for auditors' liability exposure via audit fees and large auditors } \\
\hline Fee $*$ post $*$ treatment & $\begin{array}{l}1.339 \\
(1.161)\end{array}$ & $\begin{array}{l}0.568 \\
(0.499)\end{array}$ & $\begin{array}{l}-1.271 \\
(0.957)\end{array}$ & & & \\
\hline Auditor $*$ post $*$ treatment & & & & $\begin{array}{l}0.059 \\
(0.074)\end{array}$ & $\begin{array}{l}0.048 \\
(0.043)\end{array}$ & $\begin{array}{l}0.138 \\
(0.164)\end{array}$ \\
\hline Constant & $\begin{array}{l}1.775 * * \\
(0.798)\end{array}$ & $\begin{array}{l}-0.218 \\
(0.442)\end{array}$ & $\begin{array}{l}-1.045 \\
(1.562)\end{array}$ & $\begin{array}{l}0.471 * * * \\
(0.139)\end{array}$ & $\begin{array}{l}-0.034 \\
(0.086)\end{array}$ & $\begin{array}{l}0.103 \\
(0.296)\end{array}$ \\
\hline Interaction terms & Yes & Yes & Yes & Yes & Yes & Yes \\
\hline Firm controls & Yes & Yes & Yes & Yes & Yes & Yes \\
\hline Year and firm FE & Yes & Yes & Yes & Yes & Yes & Yes \\
\hline Adjusted $\mathrm{R}^{2}$ & 0.532 & 0.371 & 0.598 & 0.038 & 0.403 & 0.542 \\
\hline Observation & 1015 & 1015 & 1015 & 8715 & 8715 & 8715 \\
\hline \multirow[t]{3}{*}{ Variables } & \multicolumn{3}{|l|}{ Audit } & \multicolumn{3}{|c|}{ Inadequate control } \\
\hline & ST ratio & LT ratio & WAM & ST ratio & LT ratio & WAM \\
\hline & I & II & III & IV & V & VI \\
\hline
\end{tabular}

Panel B: Tests for auditors' liability exposure via audit and inadequate control

\begin{tabular}{|c|c|c|c|c|c|c|}
\hline Audited $*$ post $*$ treatment & $\begin{array}{l}0.072 \\
(0.073)\end{array}$ & $\begin{array}{l}0.047 \\
(0.043)\end{array}$ & $\begin{array}{l}0.123 \\
(0.162)\end{array}$ & & & \\
\hline Inadequate $*$ post $*$ treatment & & & & $\begin{array}{l}0.050 \\
(0.073)\end{array}$ & $\begin{array}{l}0.076 \\
(0.077)\end{array}$ & $\begin{array}{l}0.199 \\
(0.244)\end{array}$ \\
\hline Constant & $\begin{array}{l}0.372 * * * \\
(0.112)\end{array}$ & $\begin{array}{l}0.010 \\
(0.061)\end{array}$ & $\begin{array}{l}0.099 \\
(0.288)\end{array}$ & $\begin{array}{l}0.380 * * * \\
(0.112)\end{array}$ & $\begin{array}{l}0.008 \\
(0.061)\end{array}$ & $\begin{array}{l}0.090 \\
(0.288)\end{array}$ \\
\hline Interaction terms & Yes & Yes & Yes & Yes & Yes & Yes \\
\hline Firm controls & Yes & Yes & Yes & Yes & Yes & Yes \\
\hline Year and firm FE & Yes & Yes & Yes & Yes & Yes & Yes \\
\hline Adjusted $\mathrm{R}^{2}$ & 0.037 & 0.403 & 0.541 & 0.038 & 0.403 & 0.542 \\
\hline Observation & 8715 & 8715 & 8715 & 8715 & 8715 & 8715 \\
\hline
\end{tabular}

This table reports analysis estimates for the interaction of Post and Treatment with variables representing “Auditors' Liability Exposure". In panel A, the analysis is conducted for the firms' total audit-related fees over total assets (Fee) and the firms with large auditors (Auditor). In Panel B, the analysis is repeated for the companies with the auditor's review on firm's financial statements (Audited), as well as, the firms with the internal control found inadequate by the auditor (Inadequate). Short-Term (ST) Ratio, Long-Term (LT) Ratio, and Weighted Average Maturity (WAM) are the dependent variables. Fee*Post*Treatment, Auditor*Post*Treatment, Audited*Post*Treatment, and Inadequate*Post*Treatment are the interaction variables of Fee, Auditor, Audited, Inadequate, Post, and Treatment. Variable definitions are available in Table 10, "Appendix". Year dummies, firm controls and firm fixed effects are included. Standard errors are clustered at the firm level

$* * *, * *$, and $*$ indicate statistical significance at the $1 \%, 5 \%$, and $10 \%$ level, respectively 


\section{Conclusion}

We examine the relation between board governance changes and corporate debt maturity. In particular, we seek to identify the impact of increased board independence on debt maturity. We control for other potential influences on debt maturity, and we use an exogenous shock - the SOX legislation leading to the SEC board independence requirement-in an experimental setting between 1996 and 2009 to identify changes in board independence. We find that, after the legislation, a larger proportion of the debt of treatment firms has relatively longer maturity as board independence increases and internal board monitoring becomes stronger. This relation is more significant for conglomerates and firms with a greater need for the internal control over managers, such as companies with a high GIM index, straight debt, less strict covenants, high intangibility, high free cash flow, high discretionary accruals, and high real earnings management, and those without majority blockholders. These results are consistent with the debt agency theory and the monitoring role of an independent board.

This study contributes to the corporate governance and capital structure literature by providing insight into the possible effect of board independence changes on debt maturity. We further investigate this relation for different characteristics of debt, organizational structure, management and firm conditions. Our findings can be a joint solution for debt agency and managerial agency issues. The findings may have implications for policymakers and corporate financial decision makers in the design of effective governance dealing with managerial and debt agency problems.

Acknowledgements We would like to thank Alex Edmans, David Dennis, Gerard Hoberg, Michael Faulkender, Murillo Campello, participants at the Financial Engineering and Banking Society Conference 2018, First International Conference of the Cardiff Corporate Governance Research Group 2018, Southwestern Finance Association Conference 2015, Financial Management European Conference 2015, International Finance and Banking Society Conference 2015, Financial Management Annual Conference 2015, and seminar participants at University of Maryland, University of Warwick, University of Exeter, University of Cambridge, Norwegian School of Economics, Norwegian Business School, Ozyegin University for their helpful comments.

OpenAccess This article is distributed under the terms of the Creative Commons Attribution 4.0 International License (http://creativecommons.org/licenses/by/4.0/), which permits unrestricted use, distribution, and reproduction in any medium, provided you give appropriate credit to the original author(s) and the source, provide a link to the Creative Commons license, and indicate if changes were made.

\section{Appendix}

See Tables 10, 11, 12, 13, 14, 15 and Fig. 5. 
Table 10 Definition of variables

\begin{tabular}{|c|c|}
\hline Variables & Description \\
\hline Short-term $(\mathrm{ST})$ ratio & $\begin{array}{l}\text { It is current liabilities over the sum of current liabilities and long-term } \\
\text { debt }\end{array}$ \\
\hline Long-term (LT) ratio & $\begin{array}{l}\text { It is the sum of the debt maturing in more than } 2 \text { years over the total } \\
\text { debt }\end{array}$ \\
\hline Weighted average maturity (WAM) & $\begin{array}{l}\text { It is calculated via multiplying the fraction of each type of debt with } \\
\text { its maturity in years }\end{array}$ \\
\hline Board independence & $\begin{array}{l}\text { It is the percentage of the independent members of the board of direc- } \\
\text { tors }\end{array}$ \\
\hline$\Delta$ Board independence & $\begin{array}{l}\text { The change in the percentage of independent directors between the } \\
\text { current and preceding year }\end{array}$ \\
\hline Treatment & $\begin{array}{l}\text { It is a dummy equal to one for firms that did not comply with the } \\
\text { board independence requirement prior to 2002, and zero otherwise }\end{array}$ \\
\hline Post & $\begin{array}{l}\text { It is a dummy equal to one for values in the post-period (2003-2009), } \\
\text { and zero otherwise }\end{array}$ \\
\hline Leverage & It is the sum of current liabilities and long-term debt over total assets \\
\hline Asset maturity & It is the ratio of the fixed assets over the annual depreciation expense \\
\hline Profitability & It is the earnings before interest and taxes over total assets \\
\hline $\mathrm{M} / \mathrm{B}$ & $\begin{array}{l}\text { It represents the market-to-book ratio and it is common shares } \\
\text { outstanding multiplied by the closing price of one share over the } \\
\text { common equity }\end{array}$ \\
\hline Size & It is the natural logarithm of total assets \\
\hline Growth & It is capital expenditures over total assets \\
\hline Tangibility & It is property, plant, and equipment total over total assets \\
\hline Cash & It is the ratio of the cash and short-term investments over total assets \\
\hline Volatility & It is the standard deviation of daily stock returns \\
\hline Yield & It's the Federal Funds Interest Rate in percentage \\
\hline HHI & $\begin{array}{l}\text { It is the Herfindahl measure for industry concentration that is com- } \\
\text { puted via the Text-based Network Industry Classification method as } \\
\text { suggested by Hoberg and Phillips (2010) }\end{array}$ \\
\hline Fee & It is audit-related fees over total assets \\
\hline Auditor & $\begin{array}{l}\text { It is a dummy equal to one for firms with a large auditor (PriceWater- } \\
\text { houseCoopers, Ernst \& Young, Deloitte \& Touche, KPMG, Arthur } \\
\text { Andersen, Grant Thornton, BDO Seidman, McGladrey \& Pullen), } \\
\text { and zero otherwise }\end{array}$ \\
\hline Audited & $\begin{array}{l}\text { It is a dummy equal to one for the firms with auditor's review on the } \\
\text { financial statements }\end{array}$ \\
\hline Inadequate & $\begin{array}{l}\text { It is a dummy equal to one if the auditor finds the firm's internal con- } \\
\text { trol inadequate, and zero otherwise }\end{array}$ \\
\hline Blockholders & It is the total percentage of shares owned by the blockholders \\
\hline NominatingFull & $\begin{array}{l}\text { It is a dummy for the firms with fully independent nominating com- } \\
\text { mittee }\end{array}$ \\
\hline Ln(BoardSize) & It is the natural logarithm of board size \\
\hline BoardIncentivePay & $\begin{array}{l}\text { It is the total } \$ \text { amount (in thousands) of incentive pay to all directors } \\
\text { in the board }\end{array}$ \\
\hline
\end{tabular}


Table 11 First stage of simultaneous equations model

\begin{tabular}{|c|c|c|c|}
\hline Variables & $\begin{array}{l}\text { Leverage } \\
\text { I }\end{array}$ & $\begin{array}{l}\text { Leverage } \\
\text { II }\end{array}$ & $\begin{array}{l}\text { Leverage } \\
\text { III }\end{array}$ \\
\hline Short-term ratio & $\begin{array}{l}-0.061 * * * \\
(0.003)\end{array}$ & & \\
\hline Long-term ratio & & $\begin{array}{l}0.188 * * * \\
(0.005)\end{array}$ & \\
\hline Weighted average maturity & & & $\begin{array}{l}0.049 * * * \\
(0.001)\end{array}$ \\
\hline Profitability & $\begin{array}{l}-0.087 * * * \\
(0.007)\end{array}$ & $\begin{array}{l}-0.069^{* * *} \\
(0.007)\end{array}$ & $\begin{array}{l}-0.033^{* * * *} \\
(0.004)\end{array}$ \\
\hline $\mathrm{M} / \mathrm{B}$ & $\begin{array}{l}0.098^{* * * *} \\
(0.020)\end{array}$ & $\begin{array}{l}0.069^{* * *} \\
(0.019)\end{array}$ & $\begin{array}{l}0.027^{*} \\
(0.015)\end{array}$ \\
\hline Size & $\begin{array}{l}0.033 \text { *** } \\
(0.002)\end{array}$ & $\begin{array}{l}0.022 * * * \\
(0.002)\end{array}$ & $\begin{array}{l}0.012 * * * \\
(0.001)\end{array}$ \\
\hline Growth & $\begin{array}{l}0.030^{*} \\
(0.018)\end{array}$ & $\begin{array}{l}0.028 \\
(0.017)\end{array}$ & $\begin{array}{l}0.045 * * * \\
(0.014)\end{array}$ \\
\hline Tangibility & $\begin{array}{l}0.079 * * * \\
(0.011)\end{array}$ & $\begin{array}{l}0.062 * * * \\
(0.011)\end{array}$ & $\begin{array}{l}0.041^{* * *} \\
(0.010)\end{array}$ \\
\hline Cash & $\begin{array}{l}-0.100 * * * \\
(0.008)\end{array}$ & $\begin{array}{l}-0.091 * * * \\
(0.008)\end{array}$ & $\begin{array}{l}-0.060 * * * \\
(0.005)\end{array}$ \\
\hline Volatility & $\begin{array}{l}0.004 \\
(0.003)\end{array}$ & $\begin{array}{l}0.002 \\
(0.003)\end{array}$ & $\begin{array}{l}0.002 \\
(0.003)\end{array}$ \\
\hline Yield & $\begin{array}{l}-0.002^{* *} \\
(0.001)\end{array}$ & $\begin{array}{l}-0.003 * * * \\
(0.001)\end{array}$ & $\begin{array}{l}-0.002 * \\
(0.001)\end{array}$ \\
\hline HHI & $\begin{array}{l}0.002 \\
(0.005)\end{array}$ & $\begin{array}{l}0.002 \\
(0.005)\end{array}$ & $\begin{array}{l}0.003 \\
(0.004)\end{array}$ \\
\hline Constant & $\begin{array}{l}0.091 * * * \\
(0.014)\end{array}$ & $\begin{array}{l}0.092 * * * \\
(0.013)\end{array}$ & $\begin{array}{l}0.086^{* * * *} \\
(0.010)\end{array}$ \\
\hline Firm fixed effects & Yes & Yes & Yes \\
\hline Year dummies & Yes & Yes & Yes \\
\hline Adjusted $\mathrm{R}^{2}$ & 0.090 & 0.144 & 0.163 \\
\hline Observation & 8715 & 8715 & 8715 \\
\hline
\end{tabular}

This table reports the first stage of simultaneous equations model estimates for Short-Term (ST) Ratio, Long-Term (LT) Ratio, and Weighted Average Maturity (WAM) along with Profitability, M/B, Size, Growth, Tangibility, Cash, Volatility, Yield, HHI as control variables. The analysis is conducted using Leverage as the dependent variable. Variable definitions are available in Table 10, "Appendix". Year dummies and firm fixed effects are included. Standard errors are clustered by firms ***, **, and $*$ indicate statistical significance at the $1 \%, 5 \%$, and $10 \%$ level, respectively 
Table 12 Difference-in-difference analysis with an alternative measure

\begin{tabular}{|c|c|c|c|}
\hline Variables & $\begin{array}{l}\text { ST ratio } \\
\text { I }\end{array}$ & $\begin{array}{l}\text { LT ratio } \\
\text { II }\end{array}$ & $\begin{array}{l}\text { WAM } \\
\text { III }\end{array}$ \\
\hline Growth $^{+}$(B. independence) & $\begin{array}{l}-0.014^{*} \\
(0.008)\end{array}$ & $\begin{array}{l}0.006 \\
(0.005)\end{array}$ & $\begin{array}{l}0.002 \\
(0.019)\end{array}$ \\
\hline Post $*$ treatment & $\begin{array}{l}0.038^{*} \\
(0.020)\end{array}$ & $\begin{array}{l}-0.025^{* *} \\
(0.012)\end{array}$ & $\begin{array}{l}-0.107 * \\
(0.056)\end{array}$ \\
\hline Growth $^{+}$(B. independence) ${ }^{*}$ post & $\begin{array}{l}0.019 \\
(0.012)\end{array}$ & $\begin{array}{l}-0.004 \\
(0.006)\end{array}$ & $\begin{array}{l}-0.004 \\
(0.024)\end{array}$ \\
\hline Growth $^{+}($B. independence $) *$ treatment & $\begin{array}{l}0.010 \\
(0.016)\end{array}$ & $\begin{array}{l}-0.015 \\
(0.010)\end{array}$ & $\begin{array}{l}0.001 \\
(0.046)\end{array}$ \\
\hline Growth $^{+}($B. independence $) *$ post $*$ treatment & $\begin{array}{l}-0.033^{*} \\
(0.019)\end{array}$ & $\begin{array}{l}0.029 * * \\
(0.014)\end{array}$ & $\begin{array}{l}0.103 * \\
(0.06)\end{array}$ \\
\hline Leverage & $\begin{array}{l}-0.383^{* * *} \\
(0.060)\end{array}$ & $\begin{array}{l}1.007 * * * \\
(0.033)\end{array}$ & $\begin{array}{l}5.886 * * * \\
(0.189)\end{array}$ \\
\hline Asset maturity & $\begin{array}{l}-0.100^{*} \\
(0.061)\end{array}$ & $\begin{array}{l}0.103 * * * \\
(0.032)\end{array}$ & $\begin{array}{l}0.493 * * * \\
(0.153)\end{array}$ \\
\hline Profitability & $\begin{array}{l}-0.103 \\
(0.081)\end{array}$ & $\begin{array}{l}-0.006 \\
(0.041)\end{array}$ & $\begin{array}{l}0.069 \\
(0.182)\end{array}$ \\
\hline $\mathrm{M} / \mathrm{B}$ & $\begin{array}{l}0.001 \\
(0.104)\end{array}$ & $\begin{array}{l}-0.283^{* * * *} \\
(0.063)\end{array}$ & $\begin{array}{l}-1.150^{* * * *} \\
(0.363)\end{array}$ \\
\hline Size & $\begin{array}{l}-0.015 \\
(0.013)\end{array}$ & $\begin{array}{l}0.010 \\
(0.007)\end{array}$ & $\begin{array}{l}0.041 \\
(0.036)\end{array}$ \\
\hline Growth & $\begin{array}{l}-0.115 \\
(0.102)\end{array}$ & $\begin{array}{l}0.151 * * \\
(0.068)\end{array}$ & $\begin{array}{l}0.578 * * \\
(0.257)\end{array}$ \\
\hline Tangibility & $\begin{array}{l}0.070 \\
(0.074)\end{array}$ & $\begin{array}{l}-0.019 \\
(0.045)\end{array}$ & $\begin{array}{l}-0.295 \\
(0.210)\end{array}$ \\
\hline Cash & $\begin{array}{l}-0.005 \\
(0.077)\end{array}$ & $\begin{array}{l}0.078^{*} \\
(0.043)\end{array}$ & $\begin{array}{l}0.210 \\
(0.154)\end{array}$ \\
\hline Volatility & $\begin{array}{l}-0.042 \\
(0.065)\end{array}$ & $\begin{array}{l}-0.097 * * \\
(0.040)\end{array}$ & $\begin{array}{l}-0.692^{* * *} \\
(0.197)\end{array}$ \\
\hline Yield & $\begin{array}{l}0.511^{*} \\
(0.295)\end{array}$ & $\begin{array}{l}-0.111 \\
(0.148)\end{array}$ & $\begin{array}{l}0.436 \\
(0.541)\end{array}$ \\
\hline $\mathrm{HHI}$ & $\begin{array}{l}0.045^{*} \\
(0.026)\end{array}$ & $\begin{array}{l}0.001 \\
(0.013)\end{array}$ & $\begin{array}{l}-0.053 \\
(0.055)\end{array}$ \\
\hline Year and firm fixed effects & Yes & Yes & Yes \\
\hline Adjusted $\mathrm{R}^{2}$ & 0.038 & 0.404 & 0.543 \\
\hline Observation & 8715 & 8715 & 8715 \\
\hline
\end{tabular}

This table reports analysis estimates for $\operatorname{Growth}^{+}$(B. independence) and its interaction with Post and Treatment along with Leverage, Leverage-(fitted), Profitability, Asset Maturity, M/B, Size, Growth, Tangibility, Cash, Volatility, Yield, HHI as control variables. The analysis is conducted using three different debt maturity measures similar to Table 3: Short-Term Ratio, Long-Term Ratio, and Weighted Average Maturity. Growth $^{+}$(B. independence) is a dummy that is equal to one if $\Delta$ Board Independence is positive, and zero if it is negative. Variable definitions are available in Table 10, "Appendix". Year dummies and firm fixed effects are included. Standard errors are clustered by firms

$* * *, * *$, and $*$ indicate statistical significance at the $1 \%, 5 \%$, and $10 \%$ level, respectively 
Table 13 Difference-in-difference analysis with non-co-opted board independence

\begin{tabular}{|c|c|c|c|}
\hline Variables & $\begin{array}{l}\text { ST ratio } \\
\text { I }\end{array}$ & $\begin{array}{l}\text { LT ratio } \\
\text { II }\end{array}$ & $\begin{array}{l}\text { WAM } \\
\text { III }\end{array}$ \\
\hline$\Delta$ Non-co-opted board independence & $\begin{array}{l}-0.103^{* *} \\
(0.048)\end{array}$ & $\begin{array}{l}0.075 * * * \\
(0.026)\end{array}$ & $\begin{array}{l}0.132 \\
(0.109)\end{array}$ \\
\hline Post $*$ treatment & $\begin{array}{l}0.031^{* *} \\
(0.015)\end{array}$ & $\begin{array}{l}-0.018 * * \\
(0.008)\end{array}$ & $\begin{array}{l}-0.115^{* *} \\
(0.054)\end{array}$ \\
\hline$\Delta$ Non-co-opted board independence $*$ post & $\begin{array}{l}0.155 * * * \\
(0.058)\end{array}$ & $\begin{array}{l}-0.067 * * \\
(0.032)\end{array}$ & $\begin{array}{l}-0.099 \\
(0.127)\end{array}$ \\
\hline$\Delta$ Non-co-opted board independence $*$ treatment & $\begin{array}{l}0.108 * \\
(0.064)\end{array}$ & $\begin{array}{l}-0.124 * * * \\
(0.035)\end{array}$ & $\begin{array}{l}-0.264^{*} \\
(0.140)\end{array}$ \\
\hline$\Delta$ Non-co-opted board independence $*$ post $*$ treatment & $\begin{array}{l}-0.868^{*} \\
(0.479)\end{array}$ & $\begin{array}{l}0.432 * \\
(0.257)\end{array}$ & $\begin{array}{l}3.014 * * * \\
(0.953)\end{array}$ \\
\hline Leverage & $\begin{array}{l}-0.361 \text { *** } \\
(0.037)\end{array}$ & $\begin{array}{l}0.992 * * * \\
(0.020)\end{array}$ & $\begin{array}{l}5.801 * * * \\
(0.198)\end{array}$ \\
\hline Asset maturity & $\begin{array}{l}-0.101^{* *} \\
(0.050)\end{array}$ & $\begin{array}{l}0.117 * * * \\
(0.028)\end{array}$ & $\begin{array}{l}0.510 * * * \\
(0.161)\end{array}$ \\
\hline Profitability & $\begin{array}{l}-0.119^{* *} \\
(0.055)\end{array}$ & $\begin{array}{l}-0.013 \\
(0.030)\end{array}$ & $\begin{array}{l}0.029 \\
(0.191)\end{array}$ \\
\hline $\mathrm{M} / \mathrm{B}$ & $\begin{array}{l}0.049 \\
(0.106)\end{array}$ & $\begin{array}{l}-0.304 * * * \\
(0.059)\end{array}$ & $\begin{array}{l}-1.460^{* * *} \\
(0.364)\end{array}$ \\
\hline Size & $\begin{array}{l}-0.010 \\
(0.010)\end{array}$ & $\begin{array}{l}0.012 * * \\
(0.006)\end{array}$ & $\begin{array}{l}0.058 \\
(0.039)\end{array}$ \\
\hline Growth & $\begin{array}{l}-0.099 \\
(0.107)\end{array}$ & $\begin{array}{l}0.136^{* *} \\
(0.060)\end{array}$ & $\begin{array}{l}0.632^{* *} \\
(0.264)\end{array}$ \\
\hline Tangibility & $\begin{array}{l}0.050 \\
(0.062)\end{array}$ & $\begin{array}{l}-0.003 \\
(0.034)\end{array}$ & $\begin{array}{l}-0.289 \\
(0.231)\end{array}$ \\
\hline Cash & $\begin{array}{l}-0.054 \\
(0.048)\end{array}$ & $\begin{array}{l}0.102 * * * \\
(0.026)\end{array}$ & $\begin{array}{l}0.298 * \\
(0.166)\end{array}$ \\
\hline Volatility & $\begin{array}{l}0.012 \\
(0.059)\end{array}$ & $\begin{array}{l}-0.087^{* * *} \\
(0.033)\end{array}$ & $\begin{array}{l}-0.697^{* * *} \\
(0.203)\end{array}$ \\
\hline Yield & $\begin{array}{l}0.438 \\
(0.285)\end{array}$ & $\begin{array}{l}-0.099 \\
(0.159)\end{array}$ & $\begin{array}{l}0.244 \\
(0.565)\end{array}$ \\
\hline $\mathrm{HHI}$ & $\begin{array}{l}0.033 \\
(0.024)\end{array}$ & $\begin{array}{l}0.003 \\
(0.013)\end{array}$ & $\begin{array}{l}-0.036 \\
(0.059)\end{array}$ \\
\hline Year and firm fixed effects & Yes & Yes & Yes \\
\hline Adjusted $\mathrm{R}^{2}$ & 0.035 & 0.394 & 0.526 \\
\hline Observation & 8715 & 8715 & 8715 \\
\hline
\end{tabular}

This table reports analysis estimates for $\Delta$ Non-Co-Opted Board Independence and its interaction with Post and Treatment along with firm control variables. Following Coles et al. (2014) we construct $\Delta$ Non-CoOpted Board Independence as the change between the current and the preceding year in the proportion of the board that consists of independent directors who were already on the board when the CEO assumed office. Short-Term (ST) Ratio, Long-Term (LT) Ratio, and Weighted Average Maturity (WAM) are the dependent variables. Variable definitions are available in Table 10, "Appendix". Year dummies and firm fixed effects are included. Standard errors are clustered at the firm level

$* * *, * *$, and $*$ indicate statistical significance at the $1 \%, 5 \%$, and $10 \%$ level, respectively 
Table 14 Difference-in-difference analysis with cash holdings factor

\begin{tabular}{llll}
\hline Variables & ST ratio & LT ratio & WAM \\
& I & II & III \\
\hline
\end{tabular}

Panel A: Analysis with firms having high cash holdings (top quartile)

\begin{tabular}{llll}
$\Delta$ Board independence & 0.146 & 0.115 & 0.312 \\
Post * treatment & $(0.311)$ & $(0.089)$ & $(0.331)$ \\
& $0.336^{*}$ & $-0.156^{* * *}$ & -0.392 \\
$\Delta$ Board independence * post & $(0.190)$ & $(0.057)$ & $(0.311)$ \\
& -0.207 & $-0.264 *$ & -0.287 \\
$\Delta$ Board independence * treatment & $(0.331)$ & $(0.139)$ & $(0.378)$ \\
& -0.727 & $-0.332^{* *}$ & -0.668 \\
$\Delta$ Board & $(0.547)$ & $(0.131)$ & $(0.540)$ \\
Independence* post* treatment & $-1.143 *$ & $3.780 * * *$ & $11.180 * *$ \\
Firm controls & $(0.689)$ & $(1.449)$ & $(5.527)$ \\
Year and firm fixed effects & Yes & Yes & Yes \\
Adjusted R & Yes & Yes & Yes \\
Observation & 0.537 & 0.589 & 0.641 \\
\hline Variables & 1627 & 1627 & 1627 \\
\hline
\end{tabular}

Panel B: Analysis with cash adjusted debt maturity measures

\begin{tabular}{llll}
$\Delta$ Board independence & -0.053 & 0.027 & 0.021 \\
Post* treatment & $(0.033)$ & $(0.022)$ & $(0.087)$ \\
& $0.025^{* *}$ & $-0.021^{* *}$ & $-0.078^{*}$ \\
$\Delta$ Board independence * post & $(0.010)$ & $(0.010)$ & $(0.043)$ \\
& 0.064 & -0.009 & -0.004 \\
$\Delta$ Board independence * treatment & $(0.041)$ & $(0.028)$ & $(0.105)$ \\
& 0.014 & -0.056 & -0.074 \\
$\Delta$ Board independence * post * treatment & $(0.042)$ & $(0.041)$ & $(0.130)$ \\
& $-0.933^{*}$ & $0.887 * *$ & $4.125^{* * *}$ \\
Firm controls & $(0.515)$ & $(0.392)$ & $(1.330)$ \\
Year and firm fixed effects & Yes & Yes & Yes \\
Adjusted $R^{2}$ & Yes & Yes & Yes \\
Observation & 0.041 & 0.423 & 0.555 \\
\hline
\end{tabular}

This table reports analysis estimates for $\Delta$ Board Independence and its interaction with Post and Treatment. In Panel A, the analysis is repeated for the firms with high Cash ratio (top quartile). Cash ratio is cash and short-term investments over total assets. In Panel B, the analysis is conducted using Adj. Short-Term (ST) Ratio, Adj. Long-Term (LT) Ratio, and Adj. Weighted Average Maturity (WAM). These are the dependent variables adjusted by (1-Cash Ratio) to mitigate the cushion effect of cash on debt. Post * Treatment, $\Delta$ Board Independence *Treatment, $\Delta$ Board Independence *Post, $\Delta$ Board Independence *Post $*$ Treatment are the interaction variables of Post, Treatment, and $\Delta$ Board Independence. Variable definitions are available in Table 10, "Appendix". Year dummies, firm controls and firm fixed effects are included. Standard errors are clustered at the firm level

$* * *, * *, *$ indicate statistical significance at the $1 \%, 5 \%$, and $10 \%$ level, respectively 
Table 15 Difference-in-difference analysis with additional control variables

\begin{tabular}{|c|c|c|c|c|c|c|}
\hline Variables & ST ratio & LT ratio & WAM & ST ratio & LT ratio & WAM \\
\hline \multicolumn{7}{|c|}{ Panel A: Analysis with bond ratings and blockholder ownership as control variables } \\
\hline$\Delta$ Board independence $*$ post $*$ treatment & $\begin{array}{l}-1.128^{*} \\
(0.675)\end{array}$ & $\begin{array}{l}0.920 * * \\
(0.412)\end{array}$ & $\begin{array}{l}4.875 * * * \\
(1.673)\end{array}$ & $\begin{array}{l}-1.178^{*} \\
(0.703)\end{array}$ & $\begin{array}{l}0.885^{* *} \\
(0.450)\end{array}$ & $\begin{array}{l}5.004 * * * \\
(1.735)\end{array}$ \\
\hline Rating & $\begin{array}{l}0.001 \\
(0.002)\end{array}$ & $\begin{array}{l}0.006 * * * \\
(0.001)\end{array}$ & $\begin{array}{l}0.037 * * * \\
(0.005)\end{array}$ & & & \\
\hline Blockholders & & & & $\begin{array}{l}-0.035 \\
(0.025)\end{array}$ & $\begin{array}{l}-0.025 \\
(0.018)\end{array}$ & $\begin{array}{l}-0.101 \\
(0.070)\end{array}$ \\
\hline Interaction terms & Yes & Yes & Yes & Yes & Yes & Yes \\
\hline Firm controls & Yes & Yes & Yes & Yes & Yes & Yes \\
\hline Year and firm FE & Yes & Yes & Yes & Yes & Yes & Yes \\
\hline Adjusted $\mathrm{R}^{2}$ & 0.035 & 0.412 & 0.554 & 0.041 & 0.405 & 0.545 \\
\hline Observation & 7123 & 7123 & 7123 & 7118 & 7118 & 7118 \\
\hline \multicolumn{7}{|c|}{ Panel B: Analysis with debt seniority and debt covenants as control variables } \\
\hline$\Delta$ Board independence $*$ post $*$ treatment & $\begin{array}{l}-0.965^{*} \\
(0.579)\end{array}$ & $\begin{array}{l}0.970 * * \\
(0.443)\end{array}$ & $\begin{array}{l}5.095 * * * \\
(1.695)\end{array}$ & $\begin{array}{l}-0.984^{*} \\
(0.589)\end{array}$ & $\begin{array}{l}0.996^{* *} \\
(0.441)\end{array}$ & $\begin{array}{l}5.263 * * * \\
(1.698)\end{array}$ \\
\hline Senior debt & $\begin{array}{l}-0.009 \\
(0.006)\end{array}$ & $\begin{array}{l}0.013 * * * \\
(0.003)\end{array}$ & $\begin{array}{l}0.078 * * * \\
(0.013)\end{array}$ & & & \\
\hline Debt covenants & & & & $\begin{array}{l}0.026 \\
(0.089)\end{array}$ & $\begin{array}{l}0.039 * * * \\
(0.009)\end{array}$ & $\begin{array}{l}0.395^{* * *} \\
(0.116)\end{array}$ \\
\hline Interaction terms & Yes & Yes & Yes & Yes & Yes & Yes \\
\hline Firm controls & Yes & Yes & Yes & Yes & Yes & Yes \\
\hline Year and firm FE & Yes & Yes & Yes & Yes & Yes & Yes \\
\hline Adjusted $\mathrm{R}^{2}$ & 0.011 & 0.406 & 0.546 & 0.010 & 0.404 & 0.543 \\
\hline Observation & 8715 & 8715 & 8715 & 8715 & 8715 & 8715 \\
\hline Variables & $\begin{array}{l}\text { ST ratio } \\
\text { I }\end{array}$ & $\begin{array}{l}\text { LT ration } \\
\text { II }\end{array}$ & $\begin{array}{l}\text { WAM } \\
\text { III }\end{array}$ & $\begin{array}{l}\text { ST ratio } \\
\text { IV }\end{array}$ & $\begin{array}{l}\text { LT ration } \\
\mathrm{V}\end{array}$ & $\begin{array}{l}\text { WAM } \\
\text { VI }\end{array}$ \\
\hline
\end{tabular}

Panel C: Analysis with CEO delta and CEO vega as control variables

\begin{tabular}{|c|c|c|c|c|c|c|}
\hline$\Delta$ Board independence $*$ post $*$ treatment & $\begin{array}{l}-1.075^{*} \\
(0.645)\end{array}$ & $\begin{array}{l}1.121 * * * \\
(0.419)\end{array}$ & $\begin{array}{l}5.768 * * * \\
(1.764)\end{array}$ & $\begin{array}{l}-1.007 * \\
(0.571)\end{array}$ & $\begin{array}{l}1.101 * * * \\
(0.419)\end{array}$ & $\begin{array}{l}5.691 * * * \\
(1.763)\end{array}$ \\
\hline CEO delta & $\begin{array}{l}0.637 \\
(0.649)\end{array}$ & $\begin{array}{l}-0.095 \\
(0.352)\end{array}$ & $\begin{array}{l}0.323^{*} \\
(0.176)\end{array}$ & & & \\
\hline CEO vega & & & & $\begin{array}{l}17.616 \\
(11.019)\end{array}$ & $\begin{array}{l}-7.485 \\
(5.991)\end{array}$ & $\begin{array}{l}-22.952 \\
(22.560)\end{array}$ \\
\hline Interaction terms & Yes & Yes & Yes & Yes & Yes & Yes \\
\hline Firm controls & Yes & Yes & Yes & Yes & Yes & Yes \\
\hline Year and firm FE & Yes & Yes & Yes & Yes & Yes & Yes \\
\hline Adjusted $\mathrm{R}^{2}$ & 0.077 & 0.536 & 0.707 & 0.081 & 0.538 & 0.706 \\
\hline Observation & 5697 & 5697 & 5697 & 5688 & 5688 & 5688 \\
\hline \multicolumn{7}{|c|}{ Panel D: Analysis with CEO tenure and CEO overconfidence as control variables } \\
\hline$\Delta$ Board independence $*$ post $*$ treatment & $\begin{array}{l}-1.132^{*} \\
(0.668)\end{array}$ & $\begin{array}{l}1.081 * * \\
(0.465)\end{array}$ & $\begin{array}{l}5.539 * * * \\
(1.799)\end{array}$ & $\begin{array}{l}-1.031 * \\
(0.624)\end{array}$ & $\begin{array}{l}0.997 * * \\
(0.414)\end{array}$ & $\begin{array}{l}5.283 * * * \\
(1.698)\end{array}$ \\
\hline Tenure & $\begin{array}{l}0.001 \\
(0.001)\end{array}$ & $\begin{array}{l}0.001 \\
(0.001)\end{array}$ & $\begin{array}{l}0.001 \\
(0.002)\end{array}$ & & & \\
\hline
\end{tabular}


Table 15 (continued)

\begin{tabular}{|c|c|c|c|c|c|c|}
\hline Variables & $\begin{array}{l}\text { ST ratio } \\
\text { I }\end{array}$ & $\begin{array}{l}\text { LT ration } \\
\text { II }\end{array}$ & $\begin{array}{l}\text { WAM } \\
\text { III }\end{array}$ & $\begin{array}{l}\text { ST ratio } \\
\text { IV }\end{array}$ & $\begin{array}{l}\text { LT ration } \\
\mathrm{V}\end{array}$ & $\begin{array}{l}\text { WAM } \\
\text { VI }\end{array}$ \\
\hline \multicolumn{4}{|l|}{ CEO overconfidence } & $\begin{array}{l}0.009 \\
(0.009)\end{array}$ & $\begin{array}{l}-0.001 \\
(0.004)\end{array}$ & $\begin{array}{l}0.012 \\
(0.019)\end{array}$ \\
\hline Interaction terms & Yes & Yes & Yes & Yes & Yes & Yes \\
\hline Firm controls & Yes & Yes & Yes & Yes & Yes & Yes \\
\hline Year and firm FE & Yes & Yes & Yes & Yes & Yes & Yes \\
\hline Adjusted $\mathrm{R}^{2}$ & 0.075 & 0.529 & 0.706 & 0.077 & 0.534 & 0.707 \\
\hline Observation & 8715 & 8715 & 8715 & 8715 & 8715 & 8715 \\
\hline \multicolumn{7}{|c|}{ Panel E: Analysis with WW-index and $S A$-index as control variables } \\
\hline$\Delta$ Board independence $*$ post $*$ treatment & $\begin{array}{l}-1.086^{*} \\
(0.657)\end{array}$ & $\begin{array}{l}0.985 * * \\
(0.416)\end{array}$ & $\begin{array}{l}5.074 * * * \\
(1.709)\end{array}$ & $\begin{array}{l}-1.083 * \\
(0.653)\end{array}$ & $\begin{array}{l}0.997 * * \\
(0.414)\end{array}$ & $\begin{array}{l}5.237 * * * \\
(1.693)\end{array}$ \\
\hline WW-index & $\begin{array}{l}-0.176 \\
(0.139)\end{array}$ & $\begin{array}{l}0.030 \\
(0.076)\end{array}$ & $\begin{array}{l}-0.095 \\
(0.364)\end{array}$ & & & \\
\hline SA-index & & & & $\begin{array}{l}-0.006 \\
(0.006)\end{array}$ & $\begin{array}{l}0.001 \\
(0.003)\end{array}$ & $\begin{array}{l}-0.012 \\
(0.019)\end{array}$ \\
\hline Interaction terms & Yes & Yes & Yes & Yes & Yes & Yes \\
\hline Firm controls & Yes & Yes & Yes & Yes & Yes & Yes \\
\hline Year and firm FE & Yes & Yes & Yes & Yes & Yes & Yes \\
\hline Adjusted $\mathrm{R}^{2}$ & 0.081 & 0.535 & 0.707 & 0.078 & 0.534 & 0.707 \\
\hline Observation & 8715 & 8715 & 8715 & 8715 & 8715 & 8715 \\
\hline
\end{tabular}

This table reports estimates for the triple interaction term along with the new control variables. In Panel A, the analysis is repeated using Rating and Blockholders, while in Panel B, the analysis is conducted using Senior Debt and Debt Covenants. Panel C shows results using CEO Delta and CEO Vega, and Panel D gives findings using Tenure and CEO Overconfidence as the new controls. Panel E provides results using $W W$-Index and SA-Index. Rating is the rating of the firm's bonds. Blockholders is the total percentage of shares owned by the blockholders. Senior Debt is a dummy equal to one for the firms with senior debt, and zero otherwise. Debt Covenants is a dummy equal to one for the firms with stronger debt covenants, and zero otherwise. CEO Delta and CEO Vega are the delta and vega of CEO option portfolio calculated with the Black-Scholes formula's partial derivative with respect to stock price and stock volatility, respectively. CEO Overconfidence is a dummy equal to one if the CEO does not exercise an option when average moneyness is high (Hirshleifer et al. 2012). WW-Index and SA-Index are Whited-Wu measure (2006) and Hadlock-Pierce measure (2010) for financial constraints, respectively. Short-Term (ST) Ratio, LongTerm (LT) Ratio, and Weighted Average Maturity (WAM) are the dependent variables. $\Delta$ Board Independence *Post * Treatment is the triple interaction term. Variable definitions are available in Table 10, "Appendix". Standard errors are clustered at the firm level

$* * *, * *$, and $*$ indicate statistical significance at the $1 \%, 5 \%$, and $10 \%$ level, respectively 


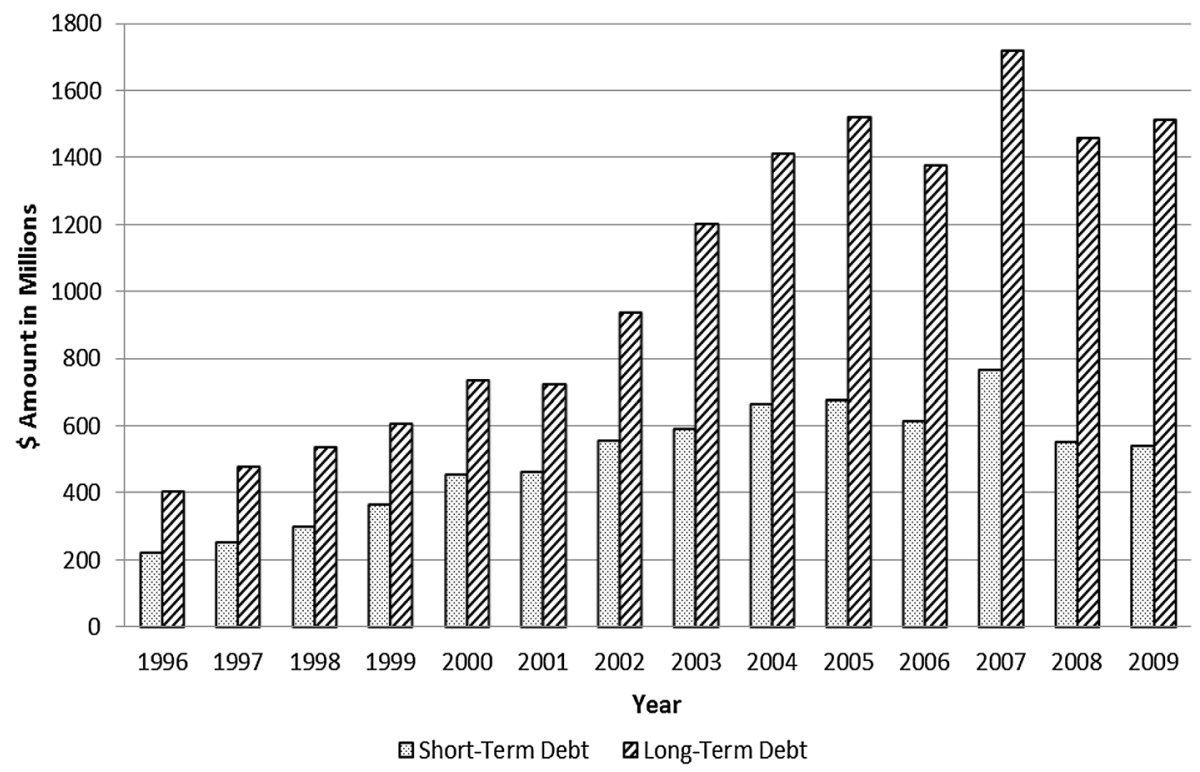

Fig. 5 Distribution of long-term and short-term debt levels. This figure presents the distribution of the annual averages for long-term and short-term debt levels between 1996 and 2009. Long-term debt is the sum of debt maturing in more than 2 years. Short-term debt is current liabilities

\section{References}

Adams RB, Ferreira D (2007) A theory of friendly boards. J Finance 62:217-250

Almeida H, Campello M, Weisbach MS (2004) The cash flow sensitivity of cash. J Finance 59:1777-1804

Anderson RC, Mansi S, Reeb DM (2004) Board characteristics, accounting report integrity, and the cost of debt. J Acc Econ 37:315-342

Arslan O, Karan MB (2006) Ownership and control structure as determinants of corporate debt maturity: a panel study of an emerging market. Corp Gov 14:312-324

Barclay MJ, Marx LM, Smith CW Jr (1995) The maturity structure of corporate debt. J Finance 50:609-631

Barclay MJ, Marx LM, Smith CW Jr (2003) The joint determination of leverage and maturity. J Corp Finance 9:149-167

Barnea A, Haugen RA, Senbet LW (1980) A rationale for debt maturity structure and call provisions in the agency theory framework. J Finance 35:1223-1234

Ben-Nasr H, Boubaker S, Rouatbi W (2015) Ownership structure, control contestability, and corporate debt maturity. J Corp Finance 35:265-285

Billett MT, King THD, Mauer DC (2007) Growth opportunities \& the choice of leverage, debt maturity and covenants. J Finance 62:697-730

Brick IE, Liao EC (2017) The joint determinants of cash holdings and debt maturity: the case for financial constraints. Rev Quant Finance Acc 48:597-614

Brockman P, Martin X, Unlu E (2010) Executive compensation and the maturity structure of corporate debt. J Finance 65:1123-1161

Chen S-S, Ho KW, Yeo GHH (1999) The determinants of debt maturity: the case of bank financing in Singapore. Rev Quant Finance Acc 12:341-350

Coles JL, Daniel ND, Naveen L (2014) Co-opted boards. Rev Financ Stud 27:1751-1796

Cotter JF, Peck SW (2001) The structure of debt and active equity investors: the case of the buyout specialist. J Financ Econ 59:101-147

Cremers KJM, Nair VB (2005) Governance mechanisms and equity prices. J Finance 60:2859-2894

Dang VA (2011) Leverage, debt maturity and firm investment: an empirical analysis. J Bus Acc $38: 225-258$ 
Duchin R, Matsusaka JG, Ozbas O (2010) When are outside directors effective? J Financ Econ 96:195-214

Elyasiani E, Guo L, Tang L (2002) The determinants of debt maturity at issuance: a system-based model. Rev Quant Finance Acc 19:351-377

Engel E, Hayes RM, Wang X (2007) The Sarbanes-Oxley Act and firms' going-private decisions. J Acc Econ 44:116-145

Enomoto M, Kimura F, Yamaguchi T (2015) Accrual-based and real earnings management: an international comparison for investor protection. J Contemp Acc Econ 11:183-198

Erhemjamts O, Raman K, Shahrur H (2010) Industry structure and corporate debt maturity. Financ Rev 45:627-657

Evans LJ, Schwartz J (2014) The effect of concentration and regulation on audit fees: an application of panel data techniques. J Empir Finance 27:130-144

Fama EF (1980) Agency problems and the theory of the firm. J Polit Econ 88:288-307

Faulkender M, Petersen MA (2006) Does the source of capital affect capital structure? Rev Financ Stud 19:45-79

Fazzari S, Hubbard RG, Petersen BC (1988) Financial constraints and corporate investment. Brook Pap Econ Act 19:141-206

Feng Z, Ghosh C, Sirmans CF (2007) ceo involvement in director selection: implications of REIT dividend policy. J Real Estate Finance Econ 35:385-410

Gatchev VA, Pulvino T, Tarhan V (2010) The interdependent and intertemporal nature of financial decisions: an application to cash flow sensitivities. J Finance 65:725-763

Gompers PA, Ishii JL, Metrick A (2003) Corporate governance and equity prices. Q J Econ 118:107-155

Goyal VK, Wang W (2013) Debt maturity and asymmetric information: evidence from default risk changes. J Financ Quant Anal 48:789-817

Green RC (1984) Investment incentives, debt, and warrants. J Financ Econ 13:115-136

Guedes J, Opler T (1996) The determinants of the maturity of corporate debt issues. J Finance 51:1809-1833

Guo LX, Masulis RW (2015) Board structure and monitoring: new evidence from CEO turnovers. Rev Financ Stud 28:2770-2811

Guo LX, Lach P, Mobbs S (2015) Tradeoffs between internal and external governance: evidence from exogenous regulatory shocks. Financ Manag 44:81-114

Gupta MC, Lee AC (2006) An integrated model of debt issuance, refunding, and maturity. Rev Quant Finance Acc 26:177-199

Hadlock CJ, Pierce JR (2010) New evidence on measuring financial constraints: moving beyond the KZ index. Rev Financ Stud 23:1909-1940

Harford J, Li K, Zhao X (2008) Corporate boards and the leverage and debt maturity choices. Int J Corp Gov 1:3-27

Haugen RA, Senbet LW (1981) Resolving the agency problems of external capital through options. J Finance 36:629-647

Hirshleifer D, Low A, Teoh SH (2012) Are overconfident CEOs better innovators? J Finance 67:1457-1498

Hoberg G, Phillips G (2010) Product market synergies and competition in mergers and acquisitions: a textbased analysis. Rev Financ Stud 23:3773-3811

Husson MR, Parrino R, Starks LT (2001) Internal monitoring mechanisms and CEO turnover: a long-term perspective. J Finance 56:2265-2297

Iliev P (2010) The effect of SOX Section 404: costs, earnings quality, and stock prices. J Finance 65:1163-1196

Jiraporn P, Kitsabunnarat P (2007) Debt maturity structure, shareholder rights and corporate governance. J Appl Finance Fall/Winter:82-96

Johnson SA (2003) Debt maturity and the effects of growth opportunities and liquidity risk on leverage. Rev Financ Stud 16:209-236

Jun S-G, Jen FC (2003) Trade-off model of debt maturity structure. Rev Quant Finance Acc 20:5-34

Jun S-G, Jen FC (2005) The determinants and implications of matching maturities. Rev Pac Basin Financ Mark Polic 8:309-337

Kaplan S, Zingales L (1997) Do investment-cash flow sensitivities provide useful measures of financing constraints. Q J Econ 112:169-215

Mitchell K (1991) The call, sinking fund and term-to-maturity features of corporate bonds: an empirical investigation. J Financ Quant Anal 26:201-223

Ozkan A (2000) An Empirical analysis of corporate debt maturity structure. Eur Financ Manag 2:197-212

Petersen MA, Rajan RG (1995) The effect of credit market competition on lending relationships. Q J Econ May:407-443 
Rokkanen N (2010) With good reputation size does not matter: issue frequency and the determinants of debt maturity. Appl Financ Econ 20:701-718

Roychowdhury S (2006) Earnings management through real activities manipulation. J Acc Econ 42:335-370

Saretto A, Tookes HE (2013) Corporate leverage, debt maturity, and credit supply: the role of credit default swaps. Rev Financ Stud 26:1190-1247

Scherr FC, Hulburt HM (2001) The debt maturity structure of small firms. Financ Manag 1:85-111

Simunic D (1980) The pricing of audit services: theory and evidence. J Acc Res 18:161-190

Stulz RM (1990) Managerial discretion and optimal financing policies. J Financ Econ 26:3-27

Stulz RM (2000) Financial structure, corporate finance and economic growth. Int Rev Finance 1:11-38

Tosun OK (2016) The effect of CEO option compensation on the capital structure: a natural experiment. Financ Manag 45:953-979

Tosun OK (2018) Changes in corporate governance: externally dictated vs voluntarily determined. Unpublished Working Paper

Whited TM, Wu G (2006) Financial constraints risk. Rev Financ Stud 19:531-559

Wintoki MB (2007) Corporate boards and regulation: the effect of the Sarbanes-Oxley Act and the exchange listing requirements on firm value. J Corp Finance 13:229-250

Zhang IX (2007) Economic consequences of the Sarbanes-Oxley Act of 2002. J Acc Econ 44:74-115

Publisher's Note Springer Nature remains neutral with regard to jurisdictional claims in published maps and institutional affiliations. 